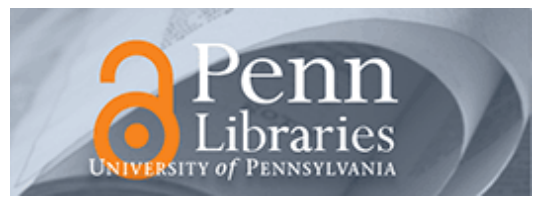

University of Pennsylvania

ScholarlyCommons

Finance Papers

Wharton Faculty Research

2017

\title{
Homeownership and Nontraditional and Subprime Mortgages
}

Arthur Acolin

University of Southern California

Xudong An

Raphael W. Bostic

Susan Wachter

University of Pennsylvania

Follow this and additional works at: https://repository.upenn.edu/fnce_papers

Part of the Finance and Financial Management Commons, Growth and Development Commons, Public Policy Commons, and the Urban Studies Commons

Recommended Citation

Acolin, A., An, X., Bostic, R. W., \& Wachter, S. (2017). Homeownership and Nontraditional and Subprime Mortgages. Housing Policy Debate, 27 (3), 393-418. http://dx.doi.org/10.1080/10511482.2016.1249003

This paper is posted at ScholarlyCommons. https://repository.upenn.edu/fnce_papers/183

For more information, please contact repository@pobox.upenn.edu. 


\title{
Homeownership and Nontraditional and Subprime Mortgages
}

\begin{abstract}
This article documents the growth and geographic distribution of nontraditional mortgages (NTMs) and subprime mortgages during 2000-2006, and examines the association between these products and homeownership at the county level between 2000 and 2012. It finds a significant relationship between the origination of NTM and subprime mortgages during the boom and changes in the number of homeowners (positive during the 2000-2006 period and negative during the 2006-2012 period) but no significant relationship with the change in the homeownership rate. Looking at specific categories of the population, the results indicate a positive relationship between the presence of NTMs and subprime mortgages and increased numbers of homeowners for young households as well as for low income and minority households, but the relationship is smaller than for the general population. Overall, the relationship between NTMs and homeownership is stronger than the relationship between subprime mortgages and homeownership during the boom and it is less negative during the bust.
\end{abstract}

\section{Keywords}

homeownership, subprime mortgages, nontraditional mortgages, credit

Disciplines

Finance and Financial Management | Growth and Development | Public Policy | Urban Studies 


\title{
Homeownership and Nontraditional and Subprime Mortgages*
}

\author{
Arthur Acolin \\ University of Southern California \\ Raphael W. Bostic \\ University of Southern California \\ Xudong An \\ San Diego State University \\ Susan M. Wachter \\ University of Pennsylvania
}

July 2016

This paper documents the growth and geographic distribution of nontraditional mortgages (NTMs) and subprime mortgages during 2000-2006, and examines the association between these products and homeownership at the county level between 2000 and 2012 . It finds a significant relationship between the origination of NTM and subprime mortgages during the boom and changes in the number of homeowners (positive during the 2000-2006 period and negative during the 2006-2012 period) but no significant relationship with the change in the homeownership rate. Looking at specific categories of the population, the results indicate a positive relationship between the presence of NTMs and subprime mortgages and increased numbers of homeowners for young households as well as for low income and minority households, but the relationship is smaller than for the general population. Overall, the relationship between NTMs and homeownership is stronger than the relationship between subprime mortgages and homeownership during the boom and it is less negative during the bust.

\footnotetext{
*The authors are grateful to Barry Cynamon and Neil Bhutta for helpful comments on an earlier version of this paper. All errors are the responsibility of the authors alone. An gratefully acknowledges data access through the UCLA Ziman Center for Real Estate during his visit of the Center. Wachter gratefully acknowledges support from the Research Sponsors Program of the Zell/Lurie Real Estate Center at The Wharton School of the University of Pennsylvania.
} 


\section{Introduction}

Most households cannot purchase a first home without a mortgage. Thus, credit markets are important for access to homeownership (Linneman and Wachter 1989). The first half of the 2000s saw significant changes and innovations in mortgage markets, perhaps most notably the increased prevalence of non-traditional mortgage products (NTMs) and an increased access to mortgages for subprime borrowers. ${ }^{1}$ In this article we define NTMs as purchase mortgages with features that differ substantially from the traditional fully-amortizing 30-year mortgages and subprime mortgages as loans to low credit score borrowers. ${ }^{2}$ We use a database that contains information on the characteristics of mortgages that are securitized in Private Label Securities (PLS) to measure the prevalence of NTM and the list of subprime lenders developed by HUD to identify subprime loans. The NTM definition is therefore based on product characteristics while subprime captures access to credit by households with low credit scores through specialized lenders.

The prevalence of NTM and subprime mortgages expanded considerably between 2001 and 2006, both absolutely and as a share of total mortgage lending across the nation. ${ }^{3}$ For NTMs, this represented an expansion into the mainstream of mortgage products that had been marginal until then. For subprime mortgages, the growth reflected an expansion of credit to increasingly marginal borrowers. While numerous papers have

\footnotetext{
${ }^{1}$ These two developments are connected but separate. Non-traditional mortgages are mortgage products with characteristics that differ substantially from the fully amortizable 30 year fixed-rate mortgages, "the American Mortgage" (Green and Wachter 2005). Subprime mortgages are loans made to borrowers with low credit score (variously defined as below 680,640 or 620 ). Many NTMs were originated to subprime borrowers and many subprime borrowers used NTMs (Bostic et al. 2012). The correlation between the share of NTM and the share of subprime mortgages at the county level is 0.7 based on the data and definition used in this paper.

${ }^{2}$ We provide more details about the datasets used to measure NTM and subprime in Section III.

${ }^{3}$ We restrict our sample to purchase mortgages here but these products were also used for refinancing.
} 
shown that the prevalence of NTMs and subprime mortgages have contributed to the run up of house price and the subsequent mortgage market crisis (see, e.g., Bostic and Lee 2008; Mian and Sufi 2011; Pavlov and Wachter 2011), little has been done regarding the association between NTMs and subprime mortgages and homeownership. As we will discuss in section II, this is an empirical question as in theory the use of NTMs and subprime mortgages could have relaxed credit constraints and thus have increased homeownership, or NTMs and subprime mortgages could have acted as substitutes of traditional mortgages and thus have had no impact on homeownership.

Moreover, this is an important issue because a popular narrative points to a role of the expansion of credit in the early 2000s in the increase in homeownership. In particular the public discourse conflates the expansion of subprime and nontraditional mortgage lending with an expansion in homeownership, particularly for low income and minority households. This relationship has actually not been examined empirically in the literature and has important implications for the role of credit supply expansion in the increase in homeownership numbers and rate during the crisis and the closing of homeownership gaps across racial and ethnic groups.

This article addresses this gap by estimating the association between the presence of NTMs and subprime mortgages at the county level between 2001 and 2006 and the change in the number and share of homeowners between 2000 and 2006 (the boom period) and 2006 and 2012 (the bust period). During the early 2000s, NTMs and subprime mortgages evolved from being niche products to representing a substantial share of mortgages used for home purchases during the housing boom to virtually disappearing following the housing bust. We develop a unique county-level dataset which 
combines census data on homeownership with public data on subprime mortgages and proprietary data for NTMs. Because we include demographic data on borrower age and racial/ethnic status we can examine the relationship of the use of these products and homeownership for subgroups as well as for the entire population.

We find a positive and significant association between NTM and subprime mortgage use and changes in the number of homeowners but no significant association with changes in the homeownership rate, during the boom period of 2000 to 2006 . We extend the examination of these relationships through 2012 and find a negative and significant association between NTMs and subprime mortgage activity and changes in the number of homeowners during the bust. Over the 2000-2012 period the relationship between the number and share of NTMs and subprime mortgages originated during the boom and changes in the number of homeowners remains positive overall.

Looking at specific categories of the population, we find a positive relationship between the presence of NTMs and subprime mortgages and increased numbers of homeowners for young households as well as for low income and minority households, but the relationship is smaller than for the general population. These results are consistent with a view that these products were not used in a way associated with increases in homeownership more by low-income and minority households. The findings suggest that the expansion of NTMs and subprime lending was not associated with a disproportionate increase in homeownership among minority and low income.

We also distinguish the relationships associated with NTMs from those associated with subprime mortgages. As above, we consider whether any differences are robust to the cycle across geographies. Overall, the relationship between NTMs and 
homeownership is stronger than the relationship between subprime mortgages and homeownership during the boom and it is less negative during the bust, pointing to a distinction between product and borrower characteristics. The paper proceeds as follows. Section II reviews the literature that has analyzed nontraditional and subprime mortgages and their impact on economic outcomes such as household consumption and prices. Section III presents the dataset and definitions we develop to document the evolution of NTMs and subprime mortgages and establish some stylized facts about each. Section IV presents the empirical exploration of the relationship between NTMs and subprime mortgages and homeownership. Section V discusses policy implications and concludes.

\section{Literature Review}

An extensive literature examines the role of the credit expansion in the recent housing boom and bust (Essene and Apgar 2007; Mayer and Pence 2008; Mian and Sufi 2011; Campbell 2012; Cocco 2013; Brueckner, Calem and Nakamura 2012; 2016; see Levitin and Wachter 2013 for a review) and whether the expansion was concentrated among low income and minority borrowers (Mian and Sufi 2011;2015) or more widespread (Adelino, Schoar and Severino 2015; 2016; Foote, Loewenstein and Willen 2016).

Rather than focusing on the means and mechanisms through which credit expanded, which has been the subject of a number of papers on this topic (Mayer and Pence 2008; Bhutta 2015; Foote, Loewenstein and Willen 2016), this paper focuses on an end product of mortgage credit - homeownership. Specifically, we ask whether the expansion of credit at the local level through NTMs and subprime mortgages was associated with an increase in the number of homeowners and in the homeownership rate. While it is often assumed 
that the expansion in credit through NTMs and subprime credit was associated with an increase in the number or share of homeowners, this need not be the case.

NTMs and subprime mortgages could have contributed to an increase in homeownership by contributing to the relaxation of credit constraints found in the literature (Barakova, Calem and Wachter 2014; Gabriel and Rosenthal 2015; Brueckner, Calem and Nakamura 2016; Acolin et al. 2016a; 2016b). Theoretical models show that NTMs and subprime mortgages can effectively remove borrowing constraints (Chinloy and Macdonald 2005; LaCour-Little and Yang 2010; Cocco 2013). Results from an experiment show that the type of credit offered affects households stated tenure choice (Fuster and Zafar 2016).

It is also possible that the expansion of NTMs and subprime mortgages was not associated with a change in the number and share of homeowners. Existing homeowners may have used NTMs and subprime mortgages to consume more housing or purchase housing in better neighborhoods or to purchase non-housing goods (Foote, Loewenstein and Willen 2016). New homeowners may have substituted NTMs and subprime mortgages for existing mortgage products. For example, borrowers may have substituted mortgages insured by FHA with subprime mortgages (Jaffee 2009; Nichols, PenningtonCross and Yezer 2005) or traditional FRM and ARM products with NTMs (LaCour-Little and Yang 2010; Amromin et al. 2011). With regards to NTMs at least (LaCour-Little and Yang 2010; Amromin et al. 2011) the evidence indicates that they were used by consumers with higher credit scores, suggesting they might have acted more on the intensive margin (the quantity of housing consumed) than on the extensive margin (new homeowners). Another reason for the possible absence of a link between homeownership 
and the use of NTMs and subprime mortgages is that investors may have disproportionately used these mortgages (Haughwout et al. 2011; Bhutta 2015). Finally, the increase in prices associated with NTM and subprime lending worked against the affordability gains possible via the features of these products, potentially limiting the number of new homeowners. In short, the relationship between these products and homeownership remains an outstanding question.

In addition, an important aspect of access to homeownership identified in the literature is the degree to which associations vary across populations, with a particular consideration of whether associations were stronger or weaker among young, low income or minority populations. Young, low-income and minority households are most affected by borrowing constraints (Haurin et al., 1997; Gyourko et al., 1999). The early literature on mortgage discrimination and redlining pointed to geographical differences at the local level in the supply of mortgage credit as impacting homeownership outcomes. More recently, Mian and Sufi (2011) point to the increase in mortgage debt in the boom years among lower income households, as a way of increasing consumption including housing consumption.

\section{The Evolution of NTMs and Subprime Mortgages over Time}

We begin by documenting trends in the volume and distribution of NTMs and subprime mortgages. ${ }^{4}$ For this paper, we use an extensive definition of NTM as any loan that substantially differs from the traditional fully amortizing and documented FRM and ARM products. A loan is classified as an NTM if it is a mortgage to purchase an individual unit (condo, co-op, single family) and has any of the following characteristics:

\footnotetext{
${ }^{4}$ For both types of product we restrict our sample to first lien purchase mortgages.
} 
(i) interest only (IO), (ii) Option-ARM with negative amortization, (iii) balloon payment, (iv) teaser rate, $(\mathrm{v})$ terms longer than 30 years, ${ }^{5}$ (vi) combined loan to value ratio (CLTV) at origination above 100 percent $^{6}$ or (vii) low or no documentation. ${ }^{7}$ The first four categories (IO, Option-ARM, Balloon and Teaser) are characterized by features enabling a backloading of payments -what Brueckner, Calem and Nakamura (2016) call alternative mortgage product (AMP) -which along with longer repayment terms address the income constraint by decreasing initial payments but result in a payment shock. No or low documentation loans can let people with irregular or undocumented assets and income qualify for a mortgage. Finally, high CLTV loans address the wealth constraint by lowering the downpayment requirement. ${ }^{8}$

We use the proprietary BlackBox dataset on private label securities (PLS) to count the number of NTMs originated in a county in a given year. ${ }^{9}$ We believe that the BlackBox data are representative of the universe of NTMs because most NTMs were securitized via PLS, although some mortgage originators kept NTM loans on portfolio.

\footnotetext{
${ }^{5}$ The threshold used is actually 365 months since mortgages with terms between 360 and 365 are not different by nature and may reflect reporting error.

${ }^{6}$ Combined Loan To Value (CLTV) combines the balance on the first and second mortgage (piggyback) to capture the overall level of leverage

${ }^{7}$ This is a comprehensive definition of NTM that goes beyond the definition of "alternative mortgage products used in LaCour-Little and Yang (2010) and Brueckner, Calem and Nakamura (2016) or of complex mortgages in Amromin et al. (2011) that restrict the definition to IO and Option ARM for example. We also tried alternative definitions by including hybrid ARMs, mortgages with prepayment penalties and changing the threshold for CLTV to strictly above 100 percent CLTV or decreasing it to 97 percent. The results are broadly similar and available upon request.

${ }^{8}$ This definition of NTM is inclusive but heterogenous and the relationship with homeownership could vary across attribute. As we show in Table 3 and discuss below, the correlation between different attributes is always above .5 but substantially below one. To test for the importance of this heterogeneity, we separated the attributes based on the type of constraint they are expected to contribute overcoming: income (Option ARM with negative amortization, Interest Only loans, loans with balloon payments, low or no doc, terms over 30 years and teaser rates), wealth (high CLTV). In both cases, the estimates are similar to those obtained with the overall NTM measure."

${ }^{9}$ BlackBox has detailed information about more than 14 million first-lien loans originated between 1998 and 2013 that were securitized in PLS.
} 
Moreover, estimates of NTM loan volumes using the BlackBox data conform to estimates using other data sources. ${ }^{10}$

The BlackBox data demonstrate that NTMs are a complex group of loans. While a mortgage could have any 1 of 7 distinct characteristics and be considered an NTM for this study, many loans originated during this period had multiple qualifying features. Table 1 shows how the mortgages are distributed along this metric for the period 20012010 among counties in our sample. We see that a majority of the loans had at least two features and a significant fraction had more than four such features.

Table 2 provides a picture of which characteristics were most common among NTMs in our sample by reporting the fraction of NTMs in a given year that had a particular feature. We see that low or no documentation were common features among NTMs in every year. By contrast, between 2001 and 2006 we see large growth in the incidence of interest only mortgages, and mortgages with a high CLTV at origination. Option-ARMs with negative amortization were the least common feature.

For subprime lending, we use data collected pursuant to the Home Mortgage Disclosure Act (HMDA). Banking and other institutions that make decisions on whether to originate a mortgage are required to report annually on all mortgage applications they receive. ${ }^{11}$ We use the number of loans issued by subprime lenders, which were identified by HUD, as our measure of the number of subprime mortgages. The HUD subprime lender list is publically available via the Urban Institute (Pettit and Droesch, 2009). This

\footnotetext{
${ }^{10}$ For example, we estimate that 31 percent of mortgages issued in 2006 were NTMs, a figure close to the 30 percent reported in Sanders (2008) using CoreLogic data and to the 32 percent reported in Inside Mortgage Finance (2013). Further, there is no evidence suggesting that NTMs kept on portfolio have a different spatial distribution than those securitized in PLS.

${ }^{11}$ Avery, et al. (2011) estimates that HMDA data cover more than 80 percent of the total mortgage origination market.
} 
list is imperfect since all loans issued by a subprime lender will be classified as subprime even if the lender also issued prime or alt-a loans. Nonetheless it offers a reasonable picture of trends over time and comparisons with other sources show that while the levels vary, the trends using HMDA are similar to those using LPS (Mayer and Pence 2008). Comparisons with measures developed using the subprime variable available in BlackBox based on the security or FICO score also show similar trends despite differences in levels with a correlation between both measures of .88. Because the HMDA based measure is estimated to be more comprehensive and is generally used in the literature we use it in the empirical analysis below.

Figure 1 shows how NTM and subprime mortgage origination volumes evolved from 1997 through 2010 for NTMs and through 2006 for subprime mortgages in counties in our sample. After being a very minor product through 2000, never totaling more than 50,000 loans, NTM incidence exploded. NTM volume doubled each year from 2001 to 2004, and annual NTM origination volume doubled again between 2004 and 2006.

Overall, NTMs increased from less than 100,000 to more than 1.7 million over this period. Similarly, while there were less than 300,000 subprime mortgage originations in 2000, there were more than 1.2 million of them in $2005 .{ }^{12}$ After 2006, the prevalence of NTMs and subprime loans dropped precipitously, as the housing crisis resulted in a rapid change in the supply of these products across the nation. By the end of our study period, NTMs had not made a comeback.

\footnotetext{
12 The way subprime loans are identified from HMDA changes after 2006, from relying on a list of subprime originators identified by HUD to being based on a spread of the mortgage rate at origination relative to prime ( 3 percentage points). In order to remain consistent and given our period of interest, the lender based definition is the only one used in this study.
} 
The rise of NTMs and subprime mortgages during the early 2000s was coupled with an increase in their market share (figure 2). NTMs were a tiny fraction of all mortgages originated from 1997 and 2001, and only first exceeded a 5 percent market share in 2003. However, the mortgage market share for NTMs rose rapidly after 2003 and topped out at about 30 percent in 2006. This rise is all the more dramatic because total mortgage lending grew by more than 2 million loans (about 40 percent) between 2001 and 2005, meaning that much of the net increase took the form of NTMs. Subprime mortgages represented about 5 percent of the market going back to the late 1990s, their share also expanded. In 2005, they represented 18 percent of the market.

Figure 2 also shows the homeownership rate during that period. It increased from 66 percent in 1997 to 69 percent in 2004, remaining at this level until 2006. In aggregate, the homeownership rate did not increase between 2004 and 2006, the period of higher supply of NTM and subprime mortgages. It then decreased back to 65 percent by 2012 . Although the homeownership rate did not increase during the 2004-2006 period, the number of homeowners kept rising by 0.9 million a year during that period, the pace slowed compared to the 1.2 million a year experienced in the $2000-2004$ period (U.S. Census 2014).

When looking at the distribution of NTMs and subprime mortgages over time and across space, we observe substantial variations across counties (figure 3). In 2003, NTMs represented more than 20 percent of mortgages in only a few places, specifically California counties concentrated in the San Francisco and Los Angeles metropolitan areas (figure 3-A). This changed significantly during 2004 and 2005, when NTM origination grew significantly in the sand states - Florida, Arizona, Nevada, and 
California - as well as in high cost markets on the east and west coasts. As seen in the second panel of figure 3-A, by 2006 the NTM origination share exceeded 20 percent in many counties, with proportions exceeding 40 percent in nearly 20 counties. Several California counties even exceeded 60 percent NTM shares in 2006. Among the top 50 counties ranked by their NTM share of all purchase originations in 2006, 37 were located in California, 5 were in Florida, 4 were in the Washington, DC metropolitan area, 2 were in the New York City metropolitan area, and 1 each was located in Hawaii and Nevada. The median NTM share was less than 20 percent in 2006, and markets in the lowest NTM share decile had percentages of less than 10 percent. Thus we see that NTM incidence was not uniform across geographies during this period.

The final panel of figure 3-A shows NTM origination activity during 2008, after the NTM boom had effectively ended (2007 shows a sharp decline). By that point NTMs did not represent more than 10 percent of originations in any county, as the supply of NTMs having rapidly retracted with the crisis.

Figure 3-B shows a relatively similar pattern with regard to the spatial distribution of subprime mortgages in 2003 and 2006, with a concentration of subprime mortgages seen in the West and in Florida. Two differences are of note. First, in 2003 subprime mortgages were more prevalent than NTMs, especially in a number of California counties. Second, the penetration of subprime mortgages in 2006 was higher than the penetration of NTMs in a number of counties in the Midwest and Northeast. In these counties, the rate of subprime mortgages was often above 30 percent.

Table 3 compares the geographic distribution of the features of NTMs and subprime mortgages. To create this table, we ranked counties according to the frequency of a given 
feature and then calculated the correlation coefficient of pairwise rankings. We find many product features are distributed similarly across counties. Correlation coefficients exceeding 0.9 were found between the distribution of mortgages with no and low documentation with the distributions of mortgages with teaser rates and with interest-only features; between the distribution of mortgages with teaser rates and interest-only loans; and between the distributions of loans with balloon payments and the distributions of loans with high CLTV and with long amortization periods. Among the NTM features, the geographic distributions of option ARMs and mortgages with high CLTVs were least alike, although a correlation coefficient of 0.55 is still high. The correlations between the geographic distributions of individual NTM features and the geographic distribution of subprime mortgages range between 0.36 and 0.54 , with a correlation coefficient between the NTM and subprime mortgage geographic distributions of 0.58 overall.

Figure 4 shows the share of NTMs and subprime mortgages across counties broken down by quintiles on three characteristics as of 2000: median house value to median income ratio as a measure of affordability and share of Hispanic and black households. The graphs show that NTMs were much more prevalent in the 2001-2006 period in counties that had a higher house value to income ratio as of 2000 , reflecting a lack of affordability. NTMs represent more than twice the share of mortgages in the least affordable counties as compared with the most affordable counties (14.5 percent versus 6.6 percent). The same relationship exists for subprime mortgages, although it is less pronounced (22.9 percent versus 16.3 percent).

We observe a similar pattern as pertains lending to counties ranked according to the prevalence of Hispanic households. NTMs and subprime mortgages were both more 
prevalent in counties with a higher share of Hispanic households (14.5 percent versus 5.8 percent for NTMs and 25 percent versus 14.9 percent for subprime mortgages).

The pattern for lending in counties ranked by the presence of black households differs from the Hispanic pattern. While we again observe an increase in the share of subprime loans as the share of black households in a county increases, the relationship is less strong. Moreover, we see no discernable pattern in the prevalence of NTMs across counties that vary in the black population share. This suggests that the NTM and subprime mortgage dynamics may differ for the black population relative to others.

Since the use of NTMs and subprime mortgages by minority and low income households is higher than in the general population (Haughwout et al. 2009; Jaffee 2009; Mian and Sufi 2011; Bayer et al. 2016) it is also possible that the relationship with homeownership might be higher. As shown in Appendix A the correlation coefficients between the share of NTM and subprime mortgages and changes in number of homeowners in the entire population and among subgroups (young, Hispanic and black) at the local level are overall positive for the period 2000 and 2006 and negative for the period 2006-2012, but there are some substantial differences in the magnitude of the coefficients across groups. We turn in the next section to examining the relationships between NTMs and subprime lending and homeownership further.

\section{Results for NTMs, Subprime Lending, and Homeownership Methodology}

To explore these associations we estimate a series of models in which we regress the change in the number of homeowners and the change in the homeownership rate on a set of additional variables plus NTM and subprime mortgage prevalence, measured by the 
number of NTMs and subprime mortgages originated and their market share. The coefficients on these latter variables are our coefficients of interest. We examine these relationships from 2000 to 2012, and thus cover changes in homeownership during the housing boom, the housing bust, and the overall cycle.

The baseline models we estimate are:

$$
\begin{aligned}
& \Delta H O_{i t+1}=\alpha_{0}+\beta_{1} X_{1 i t}+\beta_{2} X_{2 i t}+\beta_{3} X_{3 i t}+\beta_{4} N T M 0106_{i}+\gamma_{s}+u_{i s t}(1) \\
& \Delta H O_{i t+1}=\alpha_{0}+\beta_{1} X_{1 i t}+\beta_{2} X_{2 i t}+\beta_{3} X_{3 i t}+\beta_{4} \text { Subprime } 0106_{i}+\gamma_{s}+u_{i s t}(2),
\end{aligned}
$$

where $\Delta H O_{i t+1}$ represents the change in the number of homeowners ${ }^{13}$ in county $i$ over the period $t$ to $t+1(2000-2012,2000-2006 \text {, and 2006-2012) })^{14}, X_{1 i t}$ is the vector of housing market controls for county $i$ at period t, $X_{2 i t}$ is the vector of demographic controls, $X_{3 i t}$ represents the vector of job market controls, NTM0106 $i$ is the number or the share of mortgage originated that were NTMs in county $i$ over the period 2001-2006, Subprime $0106_{i}$ is the number or share of subprime mortgages and $\gamma_{s}$ represents state fixed effects that capture unobservable time-invariant state-level characteristics. ${ }^{15}$

We run alternate models with the change in the number of minority or young homeowners as the dependent variable or with the change in the homeownership rate and partition the data or introduce interaction terms as discussed further below.

\footnotetext{
${ }^{13}$ Our measure of the change in the number and share of homeowners comes from the Census and ACS and is therefore unlikely to be biased by the reporting of owner-occupy status by investors on mortgage applications as discussed in Haughwout et al. (2011).

${ }^{14}$ These periods correspond to the boom and bust period. Based on data availability for the ACS, it is not possible to measure the change in homeownership on an annual basis for the period prior to 2005 . We did also run an annual regression at the state level with lagged annual NTM and subprime numbers for the period 2000-2006 and results are similar to those found over the entire 2000-2006 period.

${ }^{15}$ Both population-weighted and non-weighted regressions were run with broadly similar results (Appendix B). The results discussed in the analysis are not weighted by population. As suggested by a reviewer we also combined the NTM and subprime measure into the same model. Due to the high level of collinearity between both measures we do not report the results. Those are available from the authors on demand.
} 
For housing market factors, we include, from the ACS, median house value, the ratio of the median rent and median house value, and the ratio of the median house value and median income. We also use the MSA-level house price index from the Federal Housing Finance Agency to measure the change in median house value over the period $t$ to $t+1$ and construct a variable measuring house price volatility over the last 5 years to account for past house price performance. ${ }^{16}$ Together, these capture price and affordability considerations, which can both influence and be influenced by the use of NTMs and subprime mortgages.

We include a vector of county-level demographic variables collected from the ACS, including number of households, mean household size, percent of family with children, percent black, percent Hispanic, percent foreign born, percent with some college education. Regarding job market conditions, we include median household income from the ACS and the annual unemployment rate from the Bureau of Labor Statistics. Finally, we include dummy variables for the state the county is in, whether a county is in an MSA and whether it is suburban. ${ }^{17}$ Table 4 reports sample statistics for these variables.

\section{Baseline results}

Given the important change in the housing market that occurred in late 2006, we first divide the sample into two periods: 2000 to 2006 (the boom) and 2006 to 2012 (the bust). Table 5 shows the results for the boom and bust periods and the overall period. ${ }^{18}$ The

\footnotetext{
${ }^{16}$ For non-MSA counties, we use the state level index for non-MSA parts of the state produced by FHFA. House price volatility is calculated as "the variance of the five-year percentage change in the price index across 13 years of quarterly values" (Gabriel and Rosenthal, 2015: 11).

${ }^{17}$ As defined by the Office of Management and Budget.

${ }^{18}$ We present results using the aggregate number of NTMs originated during 2001-2006 as the variable of interest. We also tested whether the effect changed by year, using annual lags for the number and share of NTM. We have run all the analyses for the 2006-2012 period using up to 8 period lags. We further re-
} 
analyses in Table 5 and 6 include state fixed effects to control for variation in state circumstances that might bias estimates of the NTM and subprime mortgage relationships. Appendix B provides the full regression results, reporting the coefficients for all control variables. We also show in Appendix B that a likelihood ratio test indicates that inclusion of the fixed effects improves model fit but does not affect the sign and magnitude of the coefficients of interest. We cluster standard errors at the MSA level for all specifications to account for potential correlation of the error terms at the local level. We also show the result weighted by population in the appendix but use the unweighted results throughout. $^{19}$

During the boom period (Table 5, column 1-2), increased NTM and subprime mortgage activity is associated with more homeowners, whether NTM and subprime lending are measured in number or share of loans (although not a higher homeownership rate as discussed below). For the number of loans, we use an aggregate measure of the number of NTMs or subprime loans originated during the 2001 to 2006 period. The regression indicates that the origination of 10 additional NTMs in the 2001 to 2006 period is associated with 7 additional homeowners between 2000 and 2006, while the origination of 10 additional subprime loans is associated with 4 additional homeowners, which is a smaller but a still significant increase. These results hold when we use the percentage of all mortgages in the county that were NTMs or subprime mortgages as an independent variable. The share results indicate that a 1 percentage point increase in the NTM share is associated with 731 more homeowners, and the estimate is statistically

estimated the relationships using the maximum NTM share in a county over the cycle as the independent variable. The results are robust to these alternative specifications.

${ }^{19}$ In addition, as a robustness check we ran a specification that included the change in renters. The results are robust to that specification. This suggests that counties in which there was a higher prevalence of NTM and subprime mortgages experienced a higher increase during the boom and decrease during the bust in the number of homeowners but that it was proportional to their overall population gains. 
significant. A one percentage point increase in the subprime share is associated with 166 more homeowners, a substantially smaller estimate than for the share of NTM but the estimate is also statistically significant.

Table 6 reports the results of the same set of regressions with the change in the homeownership rate as the dependent variable. The coefficients associated with the number or share of NTMs and subprime mortgages are generally not significant when using the percent change in the homeownership rate as the dependent variable for that subperiod (or for any other period).

The findings showing NTM and subprime mortgage activity as positively associated with the change in the number of homeowners in the 2000 to 2006 period are consistent with the narrative that exists regarding the role of NTMs and subprime mortgages in housing markets over the recent cycle, while the lack of relationship between the change in the rate of homeownership and NTMs and subprime mortgages is not consistent with this narrative.

We next turn to the results of the analysis for the bust period, which are shown in columns 3 and 4 of table 5 . While originations of NTMs and subprime mortgages were associated with an increase in the number of homeowners during the boom, they were associated with a decline in the number of homeowners between 2006 and 2012. Starting with subprime mortgages, we find the origination of 10 additional subprime loans during the boom was associated with a loss of about one homeowner during the bust. Similarly, we find a one percentage point increase in the share of subprime mortgages in a county is associated with 139 fewer owners. For NTMs, the origination of additional 10 mortgages in a county from 2001 to 2006 was also associated with a reduction of one homeowner in 
that county from 2007-2012. When one looks at NTM penetration, we observe that a 1 percentage point increase in the share of NTMs among mortgages originated during the boom was associated with a decline of 84 homeowners during the bust. However, none of these results are statistically significant, indicating a weaker negative association between NTMs and homeownership during the bust than what was found for subprime mortgages. For both subprime mortgages and NTMs, the magnitude of this negative relationship is smaller than the magnitude of the positive relationship during the boom.

We also present estimates of the relationship between NTM and subprime mortgage activity and homeownership over the entire sample period (table 5, column 5-6). For the 2000-2012 period, 10 additional NTMs originated is associated with 7 additional homeowners while 10 additional subprime loans originated is associated with 4 additional homeowners.

The control variables reported in Appendix B are generally of the expected sign with areas with higher income, a higher share of families, and college graduates, and a higher rent to value experiencing a larger increase in the number of homeowners over the entire period and in each subperiod while areas with a higher share of black resident, higher rent and house value experience a smaller increase.

Appendix $\mathrm{C}$ reports results for the same models as those shown in Table 5 and 6 but with the NTM and subprime mortgage measures combined. ${ }^{20}$ The results are overall similar, although they strengthen the positive association for NTMs relative to subprime mortgages. In the model with the number of NTMs and subprime mortgages, the coefficients on the measure of subprime lending become insignificant. In the model with the share of NTM and subprime mortgages, the positive association found for subprime

\footnotetext{
${ }^{20}$ We thank two anonymous referees for suggesting this additional specification.
} 
during the boom becomes negative but not statistically significant and becomes negative and significant for the overall period. The associations between NTMs and subprime mortgages and changes in homeownership rate remain insignificant across all periods in that specification as well.

Results by subgroups of homeowners and by county characteristics

We next take these general results and explore whether they hold across demographic groups of homeowners and across counties grouped by population subgroup share. We examine three dimensions of demographic groups: age, race and ethnicity, and income.

We first explore the association of homeownership and the use of NTMs and subprime loans for the young, as a proxy for first time homeowners. The literature has shown that young homeowners are particularly subject to borrowing constraints (Haurin et al. 1997). If NTMs are associated with greater homeownership, through overcoming constraints to lending, the population most likely to reflect a positive relationship between homeownership and the use of NTMs and subprime loans would be first-time homebuyers. Young homeowners, defined as homeowners whose household head is less than 35 , are a reasonable proxy for first-time homebuyers, as it is considerably less likely that such homeowners have bought multiple homes (Berson and Berson 1997).

The literature also suggests reasons that the relationships observed in the previous section might not hold across racial and ethnic subgroups. There is considerable evidence on deeper subprime mortgage penetration in communities with large minority populations than in the general population (Calem et al. 2004; Mayer and Spence 2008). There are competing arguments as to the implication of this for homeownership. On one hand, it could be that subprime mortgage (as well as NTM) products better match with the 
circumstances faced by minority borrowers, and so are more important for their access to homeownership (Cocco 2013). Alternatively, a deeper penetration could arise due to incomplete markets and predatory lending strategies that place minority households at greater risk, which ultimate manifests itself in the form of weaker or negative homeownership relationships (Gramlich 2007; Calem et al. 2009; Agarwal and Evanoff 2013; Agarwal et al. 2014). An earlier literature focused on whether minority borrowers were differentially excluded from access to borrowing for homeownership due to mortgage lending discrimination based on minority status or redlining (Guttentag and Wachter 1980; Munnell et al. 1996; Bostic et al. 2005). Indeed, "greenlining," or the minimizing of rationing and a concomitant increase in homeownership with the introduction of nonprime mortgage has been associated with the use of NTMs and subprime lending.

A similar set of arguments could be made regarding income. Calem et al. (2009) provide evidence that a larger share of prime and subprime mortgages were originated to low income borrowers during the boom. Deeper penetration could reflect better product efficacy, resulting in stronger ownership relationships, or increased vulnerability to abuse, which could lead to weaker or even negative relationships between homeownership and NTM and subprime lending.

Because our data do not identify lower-income homeowners, we can only analyze the income relationships by using county wide characteristics. We use the indirect measure of the county median income as a proxy for the presence of low-income homeowners. We stratify counties based on median income with low income counties being those in the lowest quartile and high income counties the remained counties. We then compare 
trends between both sets of counties. Tables 7 and 8 report the key results for the young and minority homebuyer analyses. ${ }^{21}$ These analyses reveal interesting findings. The homeowner relationships with both NTMs and subprime mortgages for both young and minority buyers during the boom are weaker than those for the entire population of homeowners.

First, Panel A shows the homeownership relationships for NTMs and subprime mortgages for young homeowners during the boom. Because the baseline homeownership numbers and rates differ for young households and the overall population, one cannot directly compare regression coefficients. Rather, one must standardize the coefficients to make them comparable. We do so by expressing the effects in terms of standard deviations. ${ }^{22}$ For example, a one standard deviation increase in the share of NTMs is associated with a .31 standard deviation larger change in the number of homeowners in the overall population and a .26 standard deviation larger change in the number of young homebuyers. For the share of subprime mortgages, the associations are .12 and .07 , respectively. Second, we see the opposite relationships during the bust. Here, the coefficients on NTM and subprime mortgage activity are negative, and the magnitude of the relationships is larger for young homeowners than for all homeowners together. A one standard deviation higher share of NTMs is associated with a 0.11 standard deviation larger decline for young homeowners compared to a 0.05 standard deviation larger decline for the overall population. A further difference from what was seen for the total

\footnotetext{
${ }^{21}$ We also conducted first-time homebuyer and racial group tests using two other approaches with similar results. Specifically, we create interaction terms involving the NTM and subprime mortgage metrics and the share of the county population that is either young (for the first-time homebuyer analysis) or black or Hispanic (for the racial group analysis). We also stratified our sample based on their share of young, black or Hispanic households and compared the relationship in high and low young and minority counties. The results of these analyses, which yield qualitatively similar results to the analysis reported in the text, are available upon request.

${ }^{22}$ We adopt the same approach for all subgroups.
} 
population is that the NTM relationship is larger than the subprime relationship in the bust.

Panel B and C report the results of the analysis for minority homeowners. The results for Hispanic homeowners (Panel B) indicate largely the same pattern as shown for young homeowners. We see positive relationships during the boom period, and negative relationships during the bust, with the boom coefficients exceeding the bust coefficients. However, the coefficients are smaller. For instance, a one standard deviation higher share of NTM is associated with a .3 standard deviation higher change in the number of homeowners during the 2000-2006 period for the whole population, but with a .1 higher change in the number of Hispanic homeowners. Here again, the NTM relationships are stronger than the subprime mortgage relationships in both the boom and bust periods.

The results for black homeowners (Panel C) look generally similar to those for the young and Hispanic homeowners, with two important differences. First, unlike any of the other findings, the magnitude of the subprime mortgage relationship is statistically indistinguishable from the magnitude of the NTM relationship. This is consistent with results in other work showing that subprime mortgages played a larger role in black communities than in the general population. Second, we do not observe negative relationships in the bust period between homeownership for black households and either NTMs or subprime mortgages. ${ }^{23}$

These results identify differences by subgroup. The main difference is that the positive relationship between NTM and subprime prevalence and change in the number

\footnotetext{
${ }^{23}$ We also looked at the relationships between NTMs and subprime mortgages and changes in the young, Hispanic and black homeownership. As in the general population, the relationships are not significant, indicating that areas with a larger number or share of these products did not experience a larger increase or decrease in young and minority homeownership rate during the boom or bust.
} 
of homeowner found in the general population during the boom appears to be relatively smaller for minority households and in minority and low income areas. This is consistent with the notion that for these subgroups these products might have been substitutes for existing products rather than providing additional access to homeownership. This may be behind our finding few additional new homeowners for these subgroups.

Table 8 presents the findings for the county level income-based analysis. Here, low income counties are defined as those counties with median income in the lowest quartile, and we compare experiences between this grouping of counties and those counties with median incomes in the highest quartile. There is no substantial difference between low and high income counties in the coefficients for the number of NTMs and subprime mortgages during the boom.

With regards to the share of NTMs and subprime mortgages, the positive relationship persists in counties with high median incomes, but is not seen in counties with low median incomes. For the low median income counties, the coefficients are negative, unlike in other cases, but they are not significant. This suggests that lower-income areas with higher levels of NTM and subprime mortgage activity did not experience disproportionate increases in the number of homeowners. Rather the positive relationship found between overall growth in number of homeowners and growth in NTMs and subprime loans as a share of overall loans is stronger in high income counties and either non-existent or negative in low income counties. During the bust, the coefficients are actually slightly more negative in high income counties, although the differences are largely not statistically significant. 


\section{Conclusion}

This paper explores the relationship between the rise of non-traditional mortgage products (NTMs) and subprime mortgages and homeownership, looking at experiences during the 2000s when the prevalence of both subprime and non-traditional mortgages increased dramatically. We first document the evolution of both NTMs and subprime mortgages during this period, and establish some stylized facts about their volume and geographic distribution. Origination activity in both mortgage categories grew dramatically during the early 2000s and then abruptly ended after 2006. Activity for both was concentrated in high cost markets and sand sates, though subprime mortgage activity was distributed more broadly across the United States.

We find that NTM and subprime activity was associated with an increase in the number of homeowners, but not in changes in the homeownership rate, during the boom period of 2000 to 2006, but was negatively associated with homeownership during the bust period of 2007-2012. There is no significant relationship between the prevalence of NTMs and subprime mortgages and changes in the homeownership rate at the local level during the bust. These results are specific to the periods examined here and would not necessarily hold for other periods during which NTMs and subprime mortgages represented only a small share of the mortgage market.

When considering groups most likely to face borrowing constraints, we find less of a relationship between increase in number of homeowners and use of NTMs and subprime loans then for the entire population. For young homeowners who are thought to be most hampered by credit constraints, we see a significant positive relationship between NTM and subprime mortgage prevalence and homeownership during the boom. We see no significant relationship during the bust years. For racial minorities, another key group for 
whom credit constraints are particularly binding, we observe somewhat different patterns. The results for Hispanic homeowners indicate largely the same pattern (positive association during the boom, negative but smaller relationship during the bust), but the coefficients are smaller than for young homeowners or the overall population. The results for black homeowners follow the same patterns but differ in two ways from what was observed for the other groups. First, the NTM and subprime mortgage relationships are similar in magnitude. Second, the relationships during the bust are positive and generally insignificant. Finally, the positive relationship during the boom is not higher in areas with lower income levels. Taken together, these results suggest that, while NTMs and subprime loans may be associated with increasing homeownership at the local level, these benefits vary across the population.

Finally, we find that overall the relationship between NTMs and homeownership is stronger than the relationship between subprime mortgages and homeownership during the boom but it is less negative during the bust.

These results are informative for several areas of policy concern. First, the gap in homeownership outcomes across racial and ethnic groups has been a policy issue of longstanding concern. While the literature has addressed issues on the predatory aspects of nonprime loans, it is possible that a more general outcome of such lending is the closing of homeownership gaps, for low income and minority households and for low income and minority areas. However, we find that there is no substantial difference between low and high income counties, and weaker NTM and subprime mortgage relationships for minority households. Thus, these findings do not support the conclusion 
that nontraditional lending products assisted in decreasing gaps in homeownership outcomes, geographically or by borrower racial or ethnic status.

Second, in response to the crisis, two strands of literature have taken opposite positions on the role of lending to low income households. Mian and Sufi $(2011 ; 2015)$ point to disproportionate lending to low income communities while Adelino et al. (2015; 2016) and Foote, Loewenstein and Willen (2016) point to expansion of credit across the board for households at all income levels although they do not focus on nonprime lending. Here we find that the relationship found by Mian and Sufi for lending does not hold for homeownership.

Taken together, these results call into question the view that an untargeted relaxation of borrowing constraints can result in the closing of persistent gaps across racial and ethnic groups and between groups stratified by income. Instead, they suggest that, in order to address existing homeownership gaps, more targeted measures are needed to improve access to mortgage credit in a sustainable manner. Such policies could potentially include education programs to increase financial literacy, pre-ownership counselling programs to improve consumer choice of context-appropriate mortgage products, post-homeownership counseling to ensure that the early years of homeownership are weathered smoothly, saving schemes to enable households to save for downpayments and overcome economic shocks that could threaten loan repayment, and enforcement of regulations that prevent the steering of consumers towards mortgage products that are not beneficial to them. 


\section{Reference:}

Acolin, A., Bricker, J., Calem, P. \& Wachter, S. (2016a). Borrowing Constraints and Homeownership. The American Economic Review: Papers and Proceedings, 106(5), 625-629.

Acolin, A., Bricker, J., Calem, P. \& Wachter, S. (2016b). Borrowing Constraints and Homeownership over the Recent Cycle. Wharton Real Estate Center Working Paper no. 793.

Adelino, M., Schoar, A., \& Severino, F. (2012). Credit supply and house prices: evidence from mortgage market segmentation. National Bureau of Economic Research, No. w17832.

Adelino, M., Schoar, A., \& Severino, F. (2015). Changes in buyer composition and the expansion of credit during the boom. National Bureau of Economic Research, No. w20848.

Adelino, M., Schoar, A., \& Severino, F. (2016). Loan originations and defaults in the mortgage crisis: The role of the middle class. Review of Financial Studies: hhw018.

Agarwal, S., \& Evanoff, D. D. (2013). Loan Product Steering in Mortgage Markets. Working Paper.

Agarwal, S., Amromin, G., Ben-David, I., Chomsisengphet, S., \& Evanoff, D. D. (2014). Predatory lending and the subprime crisis. Journal of Financial Economics, 113(1), 29-52.

Amromin, G., Huang, J., Sialm, C., \& Zhong, E. (2011). Complex mortgages. National Bureau of Economic Research, No. w17315.

Anundsen, A. K., \& Heebøll, C. (2016) Supply restrictions, subprime lending and regional US house prices. Journal of Housing Economics 31: 54-72.

Avery, R. B., Bhutta, N., Brevoort, K. P., \& Canner, G. B. (2011). The mortgage market in 2010: highlights from the data reported under the Home Mortgage Disclosure Act. Federal Reserve Bulletin, 97:1-82.

Barakova, I., Calem, P. S. \& Wachter, S. M. (2014). Borrowing constraints during the housing bubble. Journal of Housing Economics 24: 4-20.

Bayer, P., Ferreira, F. \& Ross, S. L. (2016). What Drives Racial and Ethnic Differences in High Cost Mortgages? The Role of High Risk Lenders. National Bureau of Economic Research, No. w22004.

Berson, D. W, and Berson, D. L. (1997). The importance of demographics in economic analysis: the unusual suspects. Business Economics, January 1, 12-16.

Bhutta, N. (2015). The ins and outs of mortgage debt during the housing boom and bust. Journal of Monetary Economics 76: 284-298.

Bostic, R. W., Calem, P. S., \& Wachter, S. M. (2005). Hitting the wall: Credit as an impediment to homeownership. Building assets, building credit: creating wealth in low-income communities, 155-172. 
Bostic, R., Chomsisengphet, S., Engel, K. C., McCoy, P. A., Pennington-Cross, A., \& Wachter, S. (2012). Mortgage product substitution and state anti-predatory lending laws: better loans and better borrowers?. Atlantic Economic Journal, 40(3), 273-294.

Bostic, R. W., \& Lee, K. O. (2008). Mortgages, risk, and homeownership among low-and moderate-income families. The American Economic Review, 310-314.

Brueckner, J. K., Calem, P. S. \& Nakamura, L. I. (2012). Subprime mortgages and the housing bubble. Journal of Urban Economics 71.2: 230-243.

Brueckner, J. K., Calem, P. S. \& Nakamura, L. I. (2016). House-Price Expectations, Alternative Mortgage Products, and Default. Journal of Money, Credit and Banking 48.1: 81-112.

Calem, P. S., Gillen, K., \& Wachter, S. (2004). The neighborhood distribution of subprime mortgage lending. The Journal of Real Estate Finance and Economics, 29(4), 393-410.

Calem, P. S., Courchane, M., \& Wachter, S. (2009). Sustainable Homeownership. Wharton Real Estate Center Working Paper.

Campbell, John Y. (2013). Mortgage market design. Review of Finance 17.1: 1-33.

Chinloy, P., \& MacDonald, N. (2005). Subprime lenders and mortgage market completion. The Journal of Real Estate Finance and Economics 30.2: 153-165.

Cocco, J. F. (2013). Evidence on the benefits of alternative mortgage products. The Journal of Finance, 68(4), 1663-1690.

Duca, J. V., Muellbauer, J. \& Murphy, A. House prices and credit constraints: Making sense of the US experience. The Economic Journal 121.552: 533-551.

Essene, R. S., \& Apgar, W. C. (2011). Understanding mortgage market behavior: Creating good mortgage options for all Americans. Joint Center for Housing Studies of Harvard University, 2007.

Foote, C. L., Loewenstein, L., \& Willen, P. S. (2016). Cross-Sectional Patterns of Mortgage Debt During the Housing Boom: Stocks and Flows. Working Paper.

Fuster, A., \& Zafar, B. (2016). To Buy or Not to Buy: Consumer Constraints in the Housing Market. The American Economic Review 106.5: 636-640.

Gabriel, S. A., \& Rosenthal, S. S. (2015). The Boom, the Bust and the Future of Homeownership. Real Estate Economics.

Goetzmann, W. N., Peng, L., \& Yen, J. (2012). The subprime crisis and house price appreciation. The Journal of Real Estate Finance and Economics 44.1-2: 36-66.

Gramlich, E. M. (2007). Subprime mortgages: America's latest boom and bust. The Urban Institute.

Guttentag, J. M., \& Wachter, S. M. (1980). Redlining and public policy. New York University, Graduate School of Business Administration, Salomon Brothers Center for the Study of Financial Institutions. 
Gyourko, J., Linneman, P., \& Wachter, S. (1999). Analyzing the relationships among race, wealth, and home ownership in America. Journal of Housing Economics, 8(2), 63-89.

Haughwout, A., Mayer, C., Tracy, J., Jaffee, D. M., \& Piskorski, T. (2009). Subprime mortgage pricing: the impact of race, ethnicity, and gender on the cost of borrowing. Brookings-Wharton Papers on Urban Affairs, 33-63.

Haughwout, A., Lee, D., Tracy, J. S., \& Van der Klaauw, W. (2011). Real estate investors, the leverage cycle, and the housing market crisis. FRB of New York Staff Report, (514).

Haurin, D. R., Hendershott, P. H., \& Wachter, S. M. (1997). Borrowing Constraints and the Tenure Choice of Young Households. Journal of Housing Research, 119.

Inside Mortgage Finance. (2013). The 2007 Mortgage Market Statistical Annual.

Jaffee, D. M. (2009). The US subprime mortgage crisis: Issues raised and lessons learned. Urbanization and Growth, 197.

LaCour-Little, M., \& Yang, J. (2010). Pay me now or pay me later: alternative mortgage products and the mortgage crisis. Real Estate Economics 38.4: 687-732.

Levitin, A. J., \& Wachter, S. (2013). Why housing?. Housing Policy Debate 23.1: 5-27.

Linneman, P., \& Wachter, S. (1989). The impacts of borrowing constraints on homeownership. Real Estate Economics, 17(4), 389-402.

Mayer, C. J., \& Pence, K. (2008). Subprime mortgages: what, where, and to whom?. National Bureau of Economic Research, No. w14083.

Mian, A, and Sufi, A. (2011). House Prices, Home Equity-Based Borrowing, and the US Household Leverage Crisis. American Economic Review 101: 2132-2156.

Mian, A. R., \& Sufi, A. (2015). Fraudulent income overstatement on mortgage applications during the credit expansion of 2002 to 2005. National Bureau of Economic Research., No. w20947.

Munnell, A. H., Tootell, G. M., Browne, L. E., \& McEneaney, J. (1996). Mortgage lending in Boston: Interpreting HMDA data. The American Economic Review, 25-53.

Nichols, J., Pennington-Cross, A, \& Yezer, A. (2005). Borrower self-selection, underwriting costs, and subprime mortgage credit supply. The Journal of Real Estate Finance and Economics 30.2: 197-219.

Pavlov, A., \& Wachter, S. (2011). Subprime lending and real estate prices. Real Estate Economics, 39(1), 1-17.

Pettit, K. L. S. \& Droesch, A. (2009). A Guide to Home Mortgage Disclosure Act Data.

Sanders, A. (2008). The subprime crisis and its role in the financial crisis. Journal of Housing Economics, 17(4), 254-261.

U.S. Census Bureau. (2014). "Housing Vacancies and Homeownership: CPS/HVS." https://www.census.gov/housing/hvs/data/histtabs.html 
Figures and Tables

Figure 1. Non-traditional mortgage and subprime originations, 1997-2010

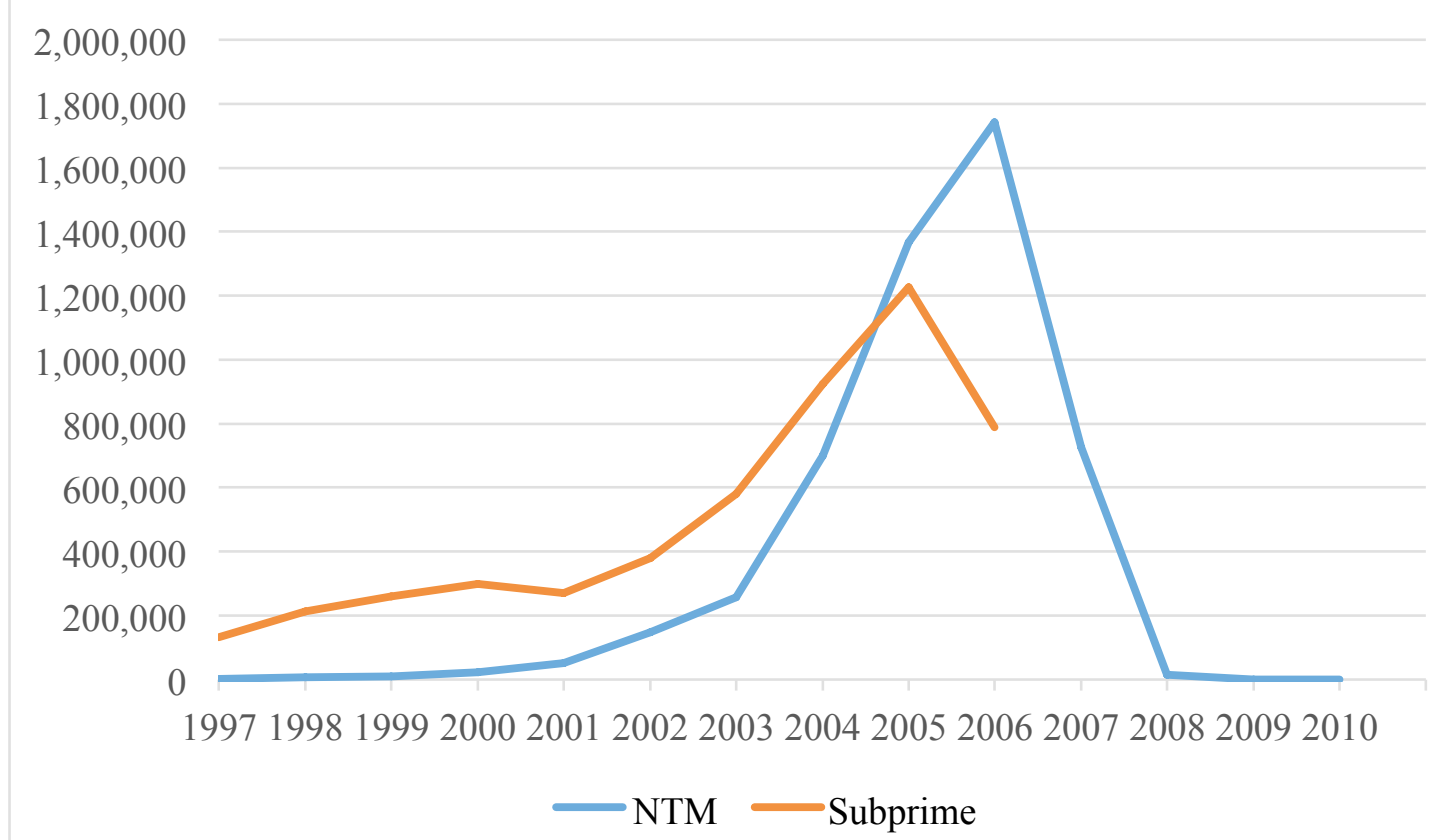

Source: BlackBox, Urban Institute calculation of HMDA. Subprime share is only shown up to 2006.

Figure 2. Non-traditional and subprime mortgages as a percentage of total purchase originations and homeownership rate, 1997-2010

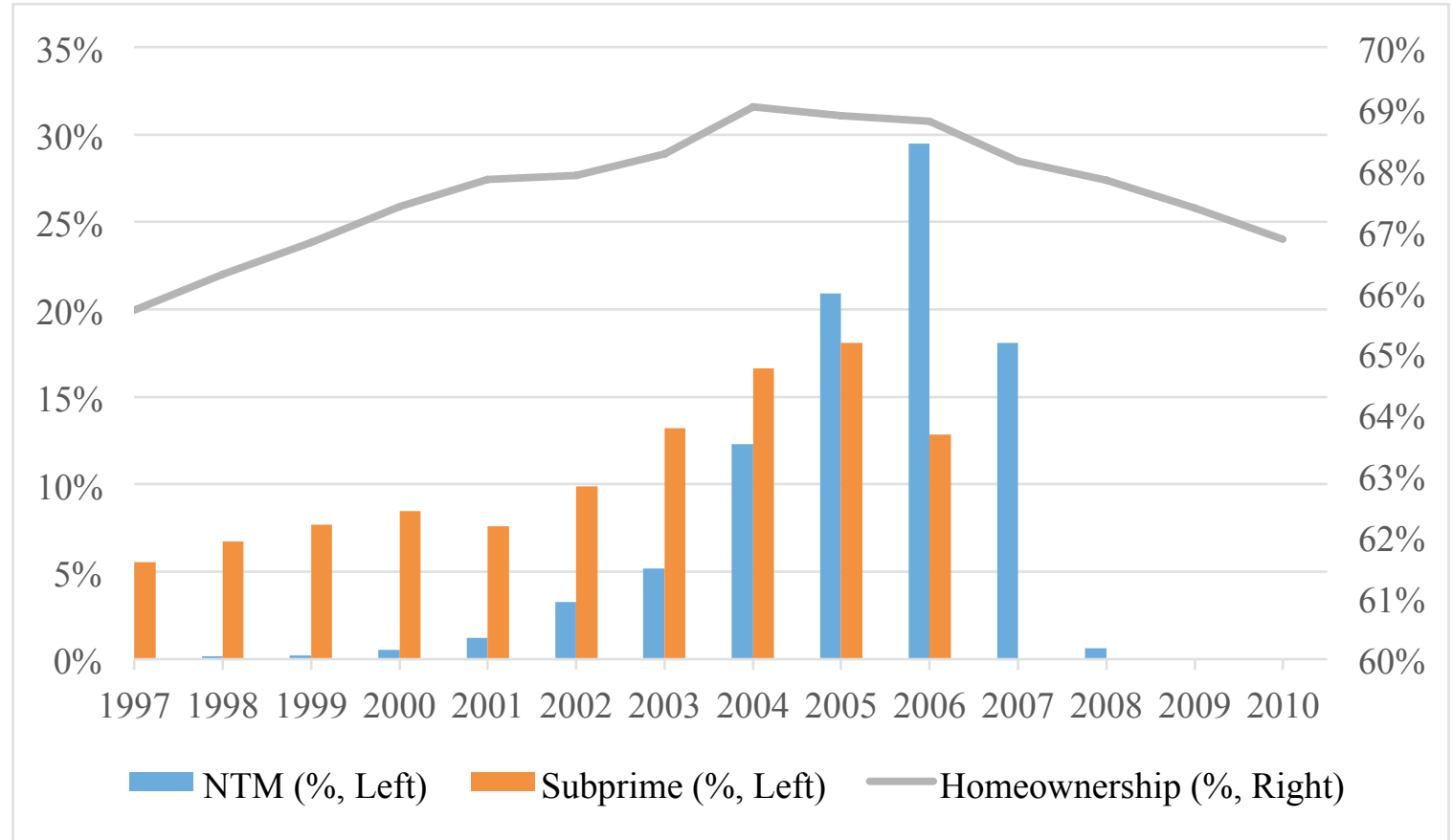

Source: HMDA, BlackBox, CPS/HVS. Subprime share is only shown up to 2006. 
Figure 3. Geographic distribution of non-traditional and subprime mortgages

Panel A. Non-traditional mortgages, 2003, 2006 and 2008

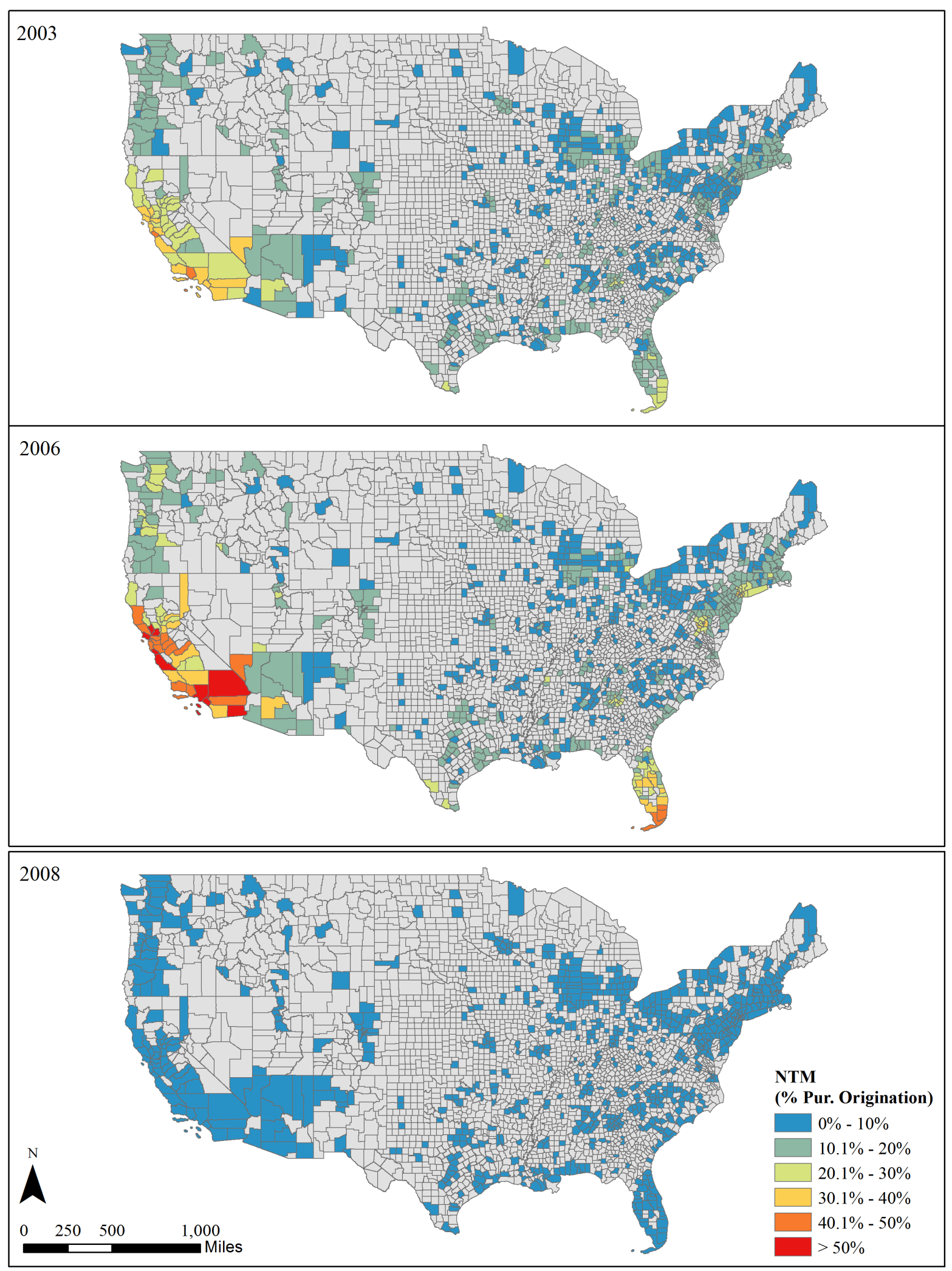

Source: HMDA, BlackBox 
Panel B. Distribution of subprime mortgages, 2003 and 2006

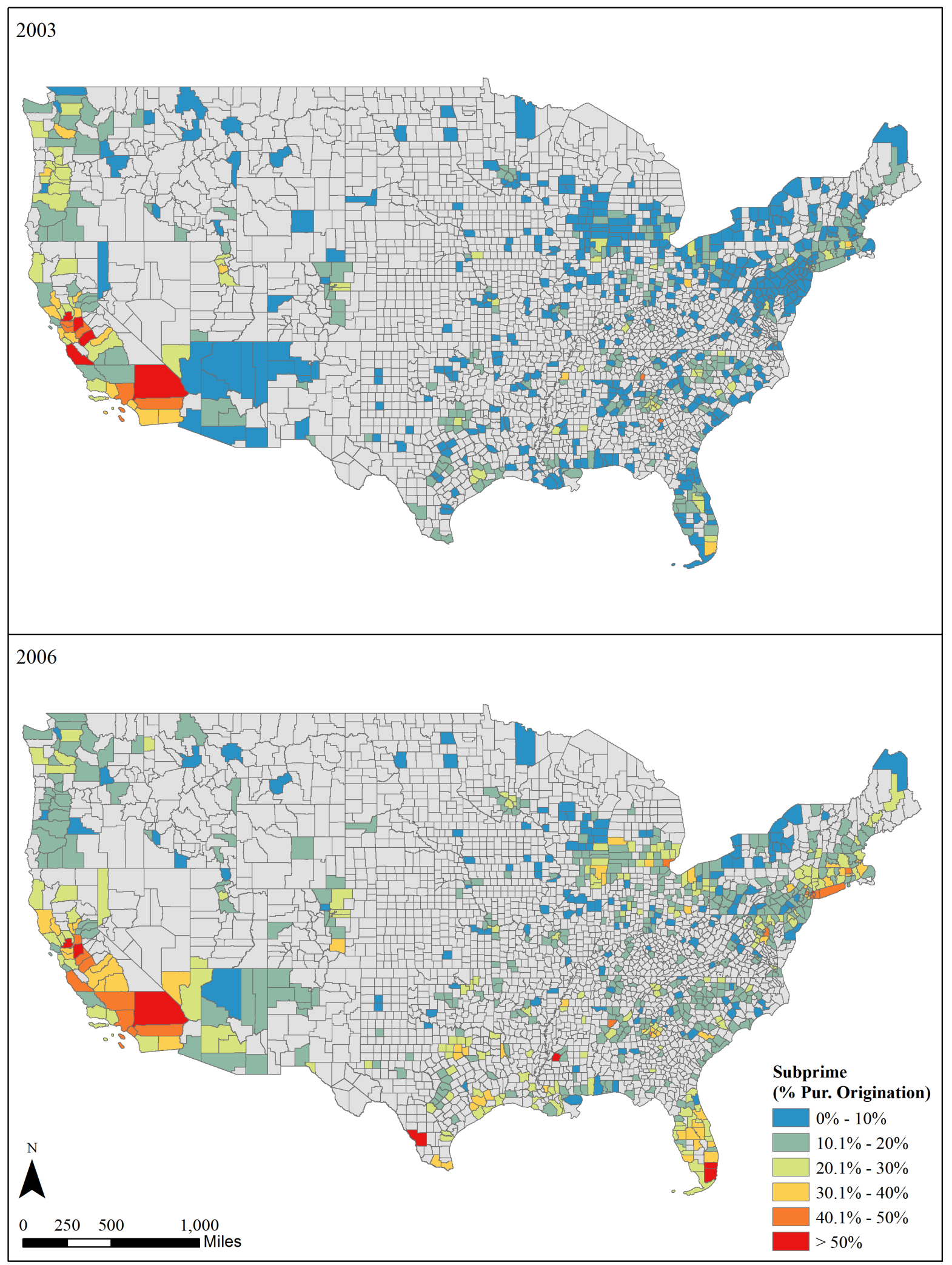

Source: HMDA, BlackBox. Subprime mortgages based on the originator definition are only available until 2006. 
Figure 4. NTM and subprime mortgage share of all mortgage originated from 2001 to 2006 , by county quintiles grouped by selected characteristics as of 2000

Panel A: NTM Share 2001-2006

i. $\quad$ Median House Value to Median Income Ratio

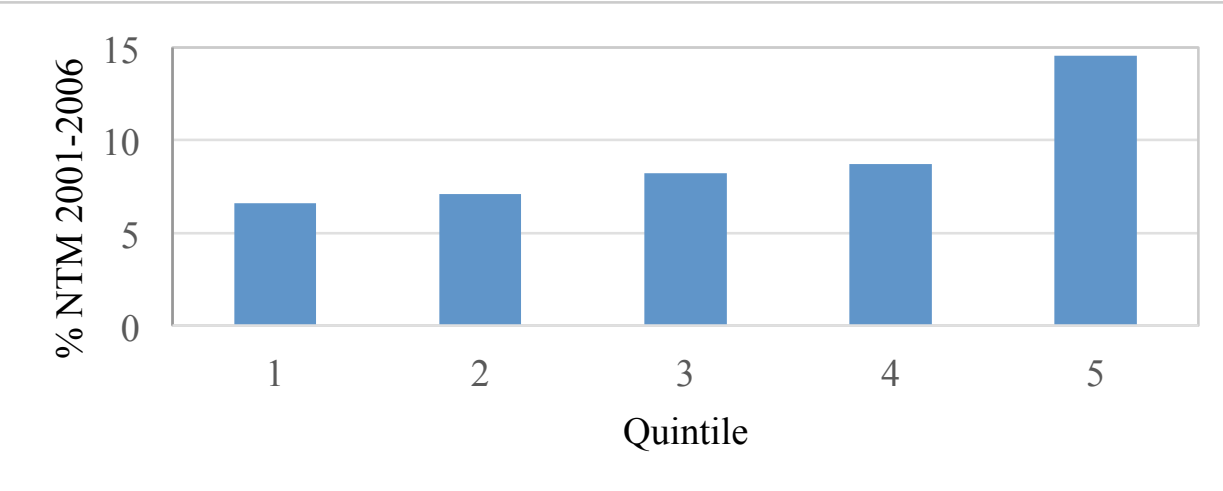

ii. $\quad$ Percent Hispanic

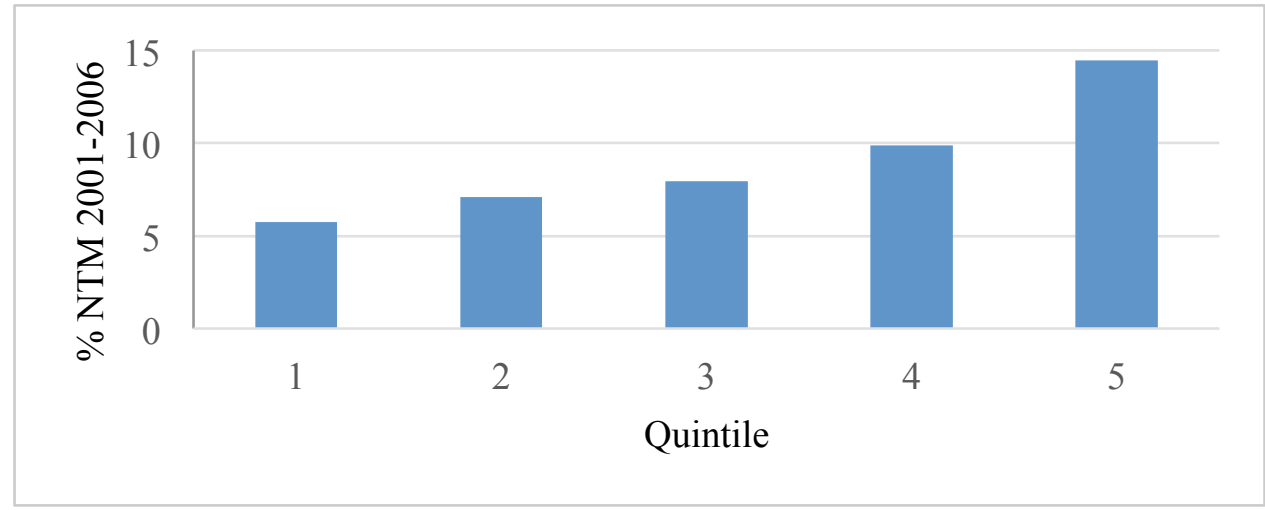

iii. Percent Black

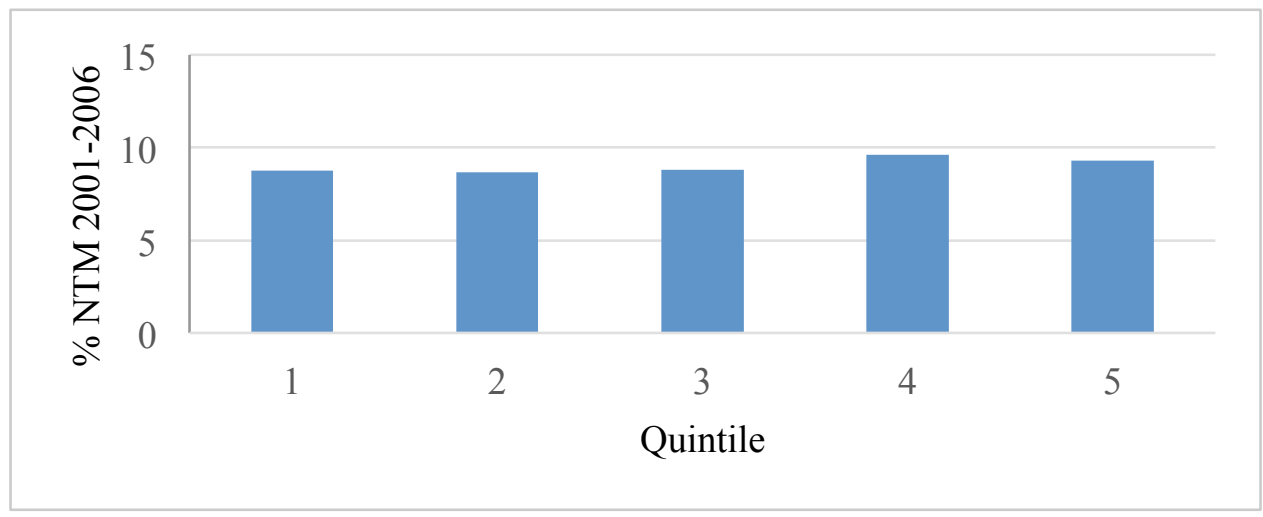

Source: HMDA, BlackBox, Census 2000. 1 = lowest quintile 
Panel B. Share of Subprime 2001-2006

i. Median House Value to Median Income Ratio

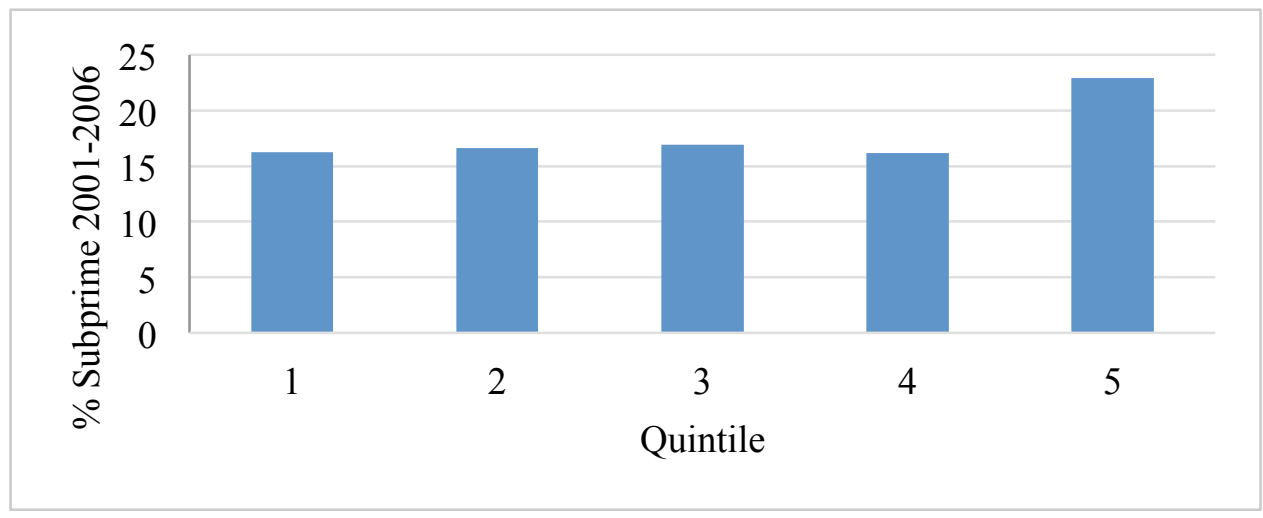

ii. Percent Hispanic

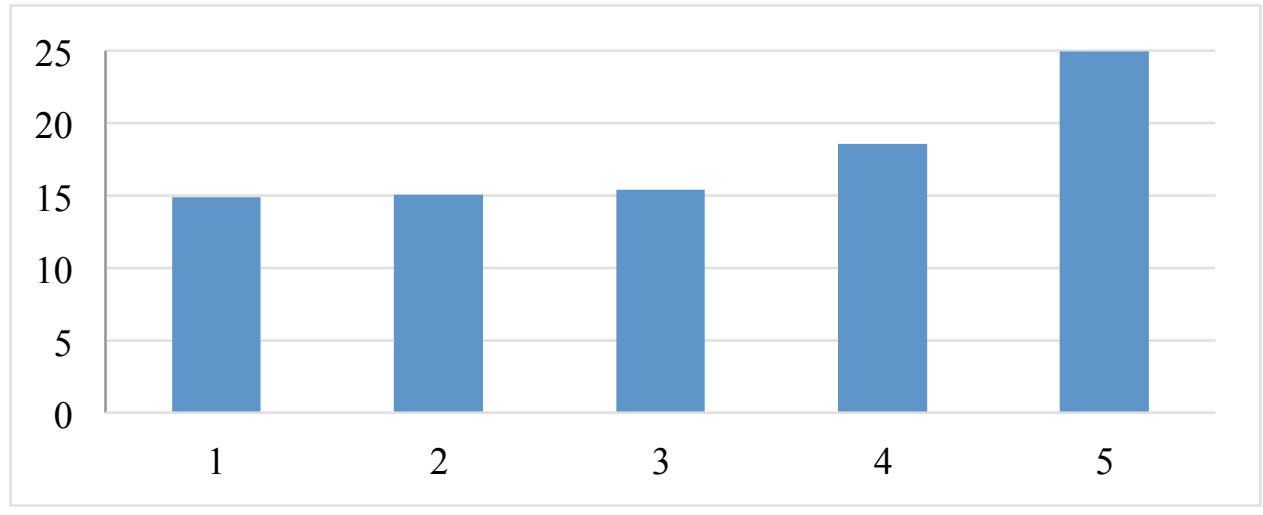

iii. Percent Black

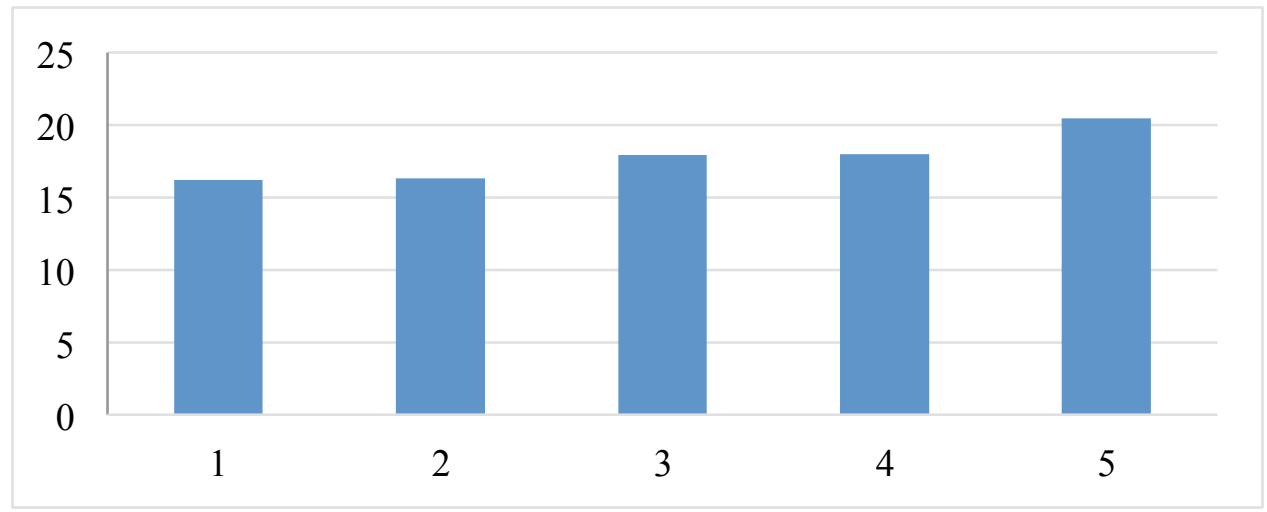

Source: HMDA, BlackBox, Census 2000 
Table 1: Number of non-traditional features by mortgage

\begin{tabular}{lrc}
\hline $\begin{array}{c}\text { Number of } \\
\text { Traits }\end{array}$ & $\begin{array}{c}\text { Number of } \\
\text { Loans }\end{array}$ & $\begin{array}{c}\text { Share of } \\
\text { Loans }\end{array}$ \\
\hline One & $2,193,571$ & $43.8 \%$ \\
Two & $1,680,978$ & $33.6 \%$ \\
Three & 863,153 & $17.2 \%$ \\
Four & 242,456 & $4.8 \%$ \\
Five & 25,595 & $0.5 \%$ \\
Six & 2,612 & $0.1 \%$ \\
Seven & 160 & $0.0 \%$ \\
Source: BlackBox & &
\end{tabular}

Source: BlackBox 
Table 2: Non-traditional and subprime mortgage volume, 2001-2008

\begin{tabular}{|c|c|c|c|c|c|c|c|c|}
\hline & 2001 & 2002 & 2003 & 2004 & 2005 & 2006 & 2007 & 2008 \\
\hline NTM & 51,771 & 147,563 & 256,068 & 700,273 & $1,368,395$ & $1,742,624$ & 725,316 & 15,941 \\
\hline Interest Only & $2.0 \%$ & $2.8 \%$ & $14.9 \%$ & $30.1 \%$ & $36.2 \%$ & $30.5 \%$ & $33.3 \%$ & $28.4 \%$ \\
\hline $\begin{array}{l}\text { Option-ARM with } \\
\text { negative amortization }\end{array}$ & $1.6 \%$ & $1.9 \%$ & $0.1 \%$ & $4.8 \%$ & $9.5 \%$ & $7.1 \%$ & $7.4 \%$ & $4.0 \%$ \\
\hline Balloon payment & $11.4 \%$ & $25.9 \%$ & $20.6 \%$ & $18.4 \%$ & $15.0 \%$ & $28.7 \%$ & $25.9 \%$ & $21.3 \%$ \\
\hline Teaser rate & $2.5 \%$ & $3.0 \%$ & $10.3 \%$ & $15.1 \%$ & $19.7 \%$ & $15.6 \%$ & $18.4 \%$ & $36.3 \%$ \\
\hline $\begin{array}{l}\text { Low or no } \\
\text { documentation }\end{array}$ & $75.8 \%$ & $70.4 \%$ & $57.9 \%$ & $48.4 \%$ & $55.8 \%$ & $59.8 \%$ & $70.3 \%$ & $57.3 \%$ \\
\hline Terms $>365$ months & $14.8 \%$ & $7.0 \%$ & $9.6 \%$ & $8.9 \%$ & $8.1 \%$ & $22.3 \%$ & $20.0 \%$ & $23.2 \%$ \\
\hline $\begin{array}{l}\text { CLTV at origination } \\
>=100\end{array}$ & $11.0 \%$ & $14.5 \%$ & $23.0 \%$ & $33.2 \%$ & $30.4 \%$ & $41.3 \%$ & $38.4 \%$ & $31.0 \%$ \\
\hline \multicolumn{9}{|l|}{ Subprime } \\
\hline HMDA Definition & 269,640 & 378,572 & 580,408 & 923,009 & $1,226,920$ & 789,564 & NA & NA \\
\hline BlackBox Definition & 44,240 & 106,174 & 167,550 & 364,477 & 602,765 & 609,852 & 160,771 & 4,404 \\
\hline
\end{tabular}

NOTE: Since many non-traditional mortgages have more than 1 non-traditional feature, the sum of the percentage adds up to more than $100 \%$

Source: BlackBox, Urban Institute calculation of HMDA 
Table 3: Correlation in penetration of different non-traditional mortgages across counties in 2006

\begin{tabular}{|c|c|c|c|c|c|c|c|c|c|}
\hline & $\begin{array}{l}\text { Interest } \\
\text { Only }\end{array}$ & $\begin{array}{c}\text { Option- } \\
\text { ARM with } \\
\text { negative } \\
\text { amortization }\end{array}$ & $\begin{array}{l}\text { Balloon } \\
\text { payment }\end{array}$ & $\begin{array}{c}\text { Teaser } \\
\text { rate }\end{array}$ & $\begin{array}{c}\text { Low or no } \\
\text { documentation }\end{array}$ & $\begin{array}{c}\text { Terms }>365 \\
\text { months }\end{array}$ & $\begin{array}{l}\text { CLTV at } \\
\text { origination } \\
>=100\end{array}$ & NTM & Subprime \\
\hline Interest Only & 1 & & & & & & & & \\
\hline $\begin{array}{l}\text { Option-ARM with } \\
\text { negative } \\
\text { amortization }\end{array}$ & 0.84 & 1 & & & & & & & \\
\hline Balloon payment & 0.76 & 0.59 & 1 & & & & & & \\
\hline Teaser rate & 0.92 & 0.78 & 0.78 & 1 & & & & & \\
\hline $\begin{array}{l}\text { Low or no } \\
\text { documentation }\end{array}$ & 0.91 & 0.82 & 0.87 & 0.92 & 1 & & & & \\
\hline $\begin{array}{l}\text { Terms }>365 \\
\text { months }\end{array}$ & 0.75 & 0.62 & 0.97 & 0.75 & 0.86 & 1 & & & \\
\hline $\begin{array}{l}\text { CLTV at } \\
\text { origination }>=100\end{array}$ & 0.77 & 0.55 & 0.93 & 0.83 & 0.86 & 0.90 & 1 & & \\
\hline Subprime & 0.46 & 0.38 & 0.46 & 0.54 & 0.52 & 0.36 & 0.54 & 0.58 & 1 \\
\hline
\end{tabular}

Source: BlackBox, Urban Institute calculation of HMDA 
Table 4. Descriptive Statistics

\begin{tabular}{|c|c|c|c|c|c|c|}
\hline & \multicolumn{3}{|c|}{2000} & \multicolumn{3}{|c|}{2006} \\
\hline & Mean & Minimum & Maximum & Mean & Minimum & Maximum \\
\hline \multicolumn{7}{|l|}{$\begin{array}{l}\text { Change in number of } \\
\text { homeowners }\end{array}$} \\
\hline $2000-2006$ & 6,425 & $-50,262$ & 133,715 & & & \\
\hline $2000-2012$ & 5,186 & $-96,183$ & 135,434 & & & \\
\hline 2006-2012 & & & & $-1,238$ & $-86,762$ & 46,872 \\
\hline NTM volume, 2001-2006 & & & & & & \\
\hline Number & 5,505 & 46 & 240,250 & 5,505 & 46 & 240,250 \\
\hline Share & 9.0 & 1.5 & 28.4 & 9.0 & 1.5 & 28.4 \\
\hline \multicolumn{7}{|l|}{$\begin{array}{l}\text { Subprime mortgage } \\
\text { volume, 2001-2006 }\end{array}$} \\
\hline Number & 9,910 & 126 & 436,165 & 9,910 & 126 & 436,165 \\
\hline Share & 17.8 & 1.4 & 62.0 & 17.8 & 1.4 & 62.0 \\
\hline Number of Households & 111,628 & 18,798 & $3,133,774$ & 118,788 & 19,118 & $3,172,032$ \\
\hline Owner Occ. $2000(\%)$ & 63.5 & 18.4 & 84.5 & 63.5 & 18.4 & 84.5 \\
\hline Mean Household Size & 2.66 & 2.07 & 3.81 & 2.66 & 2.14 & 3.83 \\
\hline College Educated (\%) & 51.3 & 27.1 & 83.8 & 53.7 & 29.7 & 82.1 \\
\hline \multicolumn{7}{|l|}{ Age share $(\%)$} \\
\hline $25-34$ & 13.6 & 7.6 & 25.4 & 13.3 & 8.2 & 19.6 \\
\hline $35-44$ & 16.0 & 10.6 & 21.7 & 14.3 & 9.6 & 20.6 \\
\hline $45-54$ & 13.6 & 7.9 & 18.4 & 14.5 & 8.2 & 19.6 \\
\hline $55-64$ & 8.8 & 4.8 & 15.1 & 10.7 & 5.8 & 16.7 \\
\hline Family with Child. (\%) & 29.9 & 15.2 & 48.8 & 31.4 & 13.8 & 48.3 \\
\hline Foreign Born (\%) & 6.3 & 0.4 & 50.9 & 7.5 & 0.3 & 50.3 \\
\hline Hispanic $(\%)$ & 7.7 & 0.3 & 94.4 & 9.4 & 0.2 & 95.1 \\
\hline Black (\%) & 9.9 & 0.1 & 66.6 & 10.5 & 0.0 & 65.7 \\
\hline Unemployment (\%) & 3.9 & 1.4 & 17.4 & 4.7 & 2.0 & 15.4 \\
\hline Med. HH Income (000) & 42.8 & 22.9 & 82.9 & 48.9 & 23.1 & 100.3 \\
\hline Med. Rent & 568 & 320 & 1,185 & 723 & 401 & 1,442 \\
\hline Med. House Value (000) & 113 & 39 & 493 & 195 & 54 & 902 \\
\hline Rent to Value (\%) & 6.5 & 2.6 & 11.2 & 6.4 & 2.0 & 15.5 \\
\hline Value to Income & 2.60 & 1.37 & 7.68 & 3.83 & 1.34 & 13.23 \\
\hline HPI Variance & 0.03 & 0.00 & 0.27 & 2.95 & 0.01 & 23.14 \\
\hline HPI Change $(\%)$ & 57.5 & 9.6 & 176.3 & -10.3 & -62.9 & 44.8 \\
\hline MSA (\%) & 87.4 & & & 87.4 & & \\
\hline Suburban County (\%) & 20.6 & & & 20.6 & & \\
\hline $\mathrm{N}$ & 732 & & & 732 & & \\
\hline
\end{tabular}


Table 5. Homeownership regression results, sample partitioned by boom and bust periods

Panel A. Non-traditional mortgages

\begin{tabular}{lcccccc}
\hline & \multicolumn{2}{c}{$2000-2006$} & \multicolumn{2}{c}{$2006-2012$} & \multicolumn{2}{c}{$2000-2012$} \\
& $(1)$ & $(2)$ & $(3)$ & $(4)$ & $(5)$ & $(6)$ \\
\hline NTM 2001- & $0.717^{* * *}$ & & -0.0758 & & $0.693^{* * *}$ & \\
2006 (\#) & $(0.121)$ & & $(0.0894)$ & & $(0.146)$ & \\
NTM 2001- & & $731.0^{* * *}$ & & -83.88 & & $510.1^{* *}$ \\
2006 (\%) & & $(197.1)$ & & $(99.62)$ & & $(206.9)$ \\
\hline Observations & 729 & 729 & 729 & 729 & 729 & 729 \\
R-squared & 0.724 & 0.617 & 0.636 & 0.634 & 0.506 & 0.415 \\
\hline
\end{tabular}

Panel B. Subprime Mortgages

\begin{tabular}{lcccccc}
\hline & \multicolumn{2}{c}{$2000-2006$} & \multicolumn{2}{c}{$2006-2012$} & \multicolumn{2}{c}{$2000-2012$} \\
& $(1)$ & $(2)$ & $(3)$ & $(4)$ & $(5)$ & $(6)$ \\
\hline Subprime & $0.433^{* * *}$ & & $-0.103^{* *}$ & & $0.375^{* * *}$ & \\
2001-2006 (\#) & $(0.0763)$ & & $(0.0446)$ & & $(0.0943)$ & \\
Subprime & & $165.8^{* *}$ & & $-139.2^{* * *}$ & & -14.70 \\
2001-2006 (\%) & & $(73.85)$ & & $(43.60)$ & & $(78.16)$ \\
\hline Observations & 729 & 729 & 729 & 729 & 729 & 729 \\
R-squared & 0.706 & 0.610 & 0.645 & 0.639 & 0.476 & 0.410 \\
\hline
\end{tabular}

NOTE: $* * * p<0.01, * * p<0.05, * p<0.1$. Robust standard errors are in parentheses. The dependent variable is the change in the number of homeowners in a county between 2000 and 2006 or 2006 and 2012. These regressions include state fixed effects, whether a county is in an MSA or not and is suburban or not and control for county household number, household size, age structure, share of family with children, college graduate, foreign born, black, Hispanic, median household income, median house value, median gross rent, rent to value ratio, value to income, HPI variance and HPI change, and 2000 homeownership rate. 
Table 6. Homeownership rate regression results

Panel A. Non-traditional mortgages

\begin{tabular}{|c|c|c|c|c|c|c|}
\hline & \multicolumn{2}{|c|}{$2000-2006$} & \multicolumn{2}{|c|}{$2006-2012$} & \multicolumn{2}{|c|}{$2000-2012$} \\
\hline & (1) & (2) & (3) & (4) & (5) & (6) \\
\hline $\begin{array}{l}\text { NTM 2001-2006 } \\
(\#)\end{array}$ & $\begin{array}{c}1.38 \mathrm{e}-05 \\
(1.63 \mathrm{e}-05)\end{array}$ & & $\begin{array}{l}-9.38 \mathrm{e}-06 \\
(2.01 \mathrm{e}-05)\end{array}$ & & $\begin{array}{l}-6.85 \mathrm{e}-06 \\
(2.01 \mathrm{e}-05)\end{array}$ & \\
\hline $\begin{array}{l}\text { NTM 2001-2006 } \\
(\%)\end{array}$ & & $\begin{array}{l}0.00449 \\
(0.0705)\end{array}$ & & $\begin{array}{l}-0.0373 \\
(0.105)\end{array}$ & & $\begin{array}{r}-0.0487 \\
(0.103)\end{array}$ \\
\hline Observations & 729 & 729 & 729 & 729 & 729 & 729 \\
\hline R-squared & 0.410 & 0.409 & 0.273 & 0.273 & 0.388 & 0.388 \\
\hline
\end{tabular}

$\underline{\text { Panel B. Subprime mortgages }}$

\begin{tabular}{|c|c|c|c|c|c|c|}
\hline & \multicolumn{2}{|c|}{$2000-2006$} & \multicolumn{2}{|c|}{ 2006-2012 } & \multicolumn{2}{|c|}{$2000-2012$} \\
\hline & (1) & (2) & (3) & (4) & $(5)$ & (6) \\
\hline $\begin{array}{l}\text { Subprime 2001- } \\
2006(\#)\end{array}$ & $\begin{array}{l}2.03 \mathrm{e}-05^{*} \\
(1.05 \mathrm{e}-05)\end{array}$ & & $\begin{array}{l}-2.67 \mathrm{e}-06 \\
(1.24 \mathrm{e}-05)\end{array}$ & & $\begin{array}{c}4.57 \mathrm{e}-06 \\
(1.26 \mathrm{e}-05)\end{array}$ & \\
\hline $\begin{array}{l}\text { Subprime } 2001- \\
2006(\%)\end{array}$ & & $\begin{array}{c}0.0232 \\
(0.0306)\end{array}$ & & $\begin{array}{l}-0.0476 \\
(0.0380)\end{array}$ & & $\begin{array}{l}-0.0284 \\
(0.0300)\end{array}$ \\
\hline Observations & 729 & 729 & 729 & 729 & 729 & 729 \\
\hline R-squared & 0.411 & 0.410 & 0.273 & 0.275 & 0.388 & 0.388 \\
\hline
\end{tabular}

NOTE: $* * * \mathrm{p}<0.01, * * \mathrm{p}<0.05, * \mathrm{p}<0.1$. Robust standard errors are in parentheses. The dependent variable is the percent change in the homeownership rate in a county between 2000 and 2006, 2006 and 2012 and 2000 and 2012. Each coefficient represents the result of a separate regression estimated using the same specification as in tables 5 . 
Table 7. Homeownership regression results, with change in the number of young and minority homeowners as the dependent variable

Panel A. Young Homeowners

i. Non-traditional mortgages

\begin{tabular}{lcccc}
\hline & \multicolumn{2}{c}{$2000-2006$} & \multicolumn{2}{c}{$2006-2012$} \\
& $(1)$ & $(2)$ & $(3)$ & $(4)$ \\
\hline NTM 2001-2006 & $0.166^{* * *}$ & & $-0.143 * * *$ & \\
$(\#)$ & $(0.0397)$ & & $(0.0363)$ & \\
NTM 2001-2006 & & $128.1 * *$ & & $-69.94 * *$ \\
$(\%)$ & & $(50.92)$ & & $(31.20)$ \\
& & & & \\
\hline Observations & 729 & 729 & 729 & 729 \\
R-squared & 0.430 & 0.263 & 0.749 & 0.740 \\
\hline
\end{tabular}

ii. Subprime mortgages

\begin{tabular}{lcccc}
\hline & \multicolumn{2}{c}{$2000-2006$} & \multicolumn{2}{c}{$2006-2012$} \\
& $(1)$ & $(2)$ & $(3)$ & $(4)$ \\
\hline Subprime 2001-2006 & $0.113 * * *$ & \multicolumn{3}{c}{$-0.0993 * * *$} \\
$(\#)$ & $(0.0238)$ & & $(0.0182)$ & \\
Subprime 2001-2006 & & 19.29 & & $-36.91 * *$ \\
$(\%)$ & & $(20.44)$ & & $(14.44)$ \\
& & & & \\
\hline Observations & 729 & 729 & 729 & 729 \\
R-squared & 0.433 & 0.252 & 0.755 & 0.685 \\
\hline
\end{tabular}

NOTE: $* * * \mathrm{p}<0.01, * * \mathrm{p}<0.05, * \mathrm{p}<0.1$. Robust standard errors are in parentheses. Each coefficient represents the result of a separate regression estimated using the same specification as in tables 5 . The dependent variable for each regression is the change in the number of young homeowners in a county between 2000 and 2006 or 2006 and 2012. 
Panel B. Hispanic homeownership

i. Non-traditional mortgages

\begin{tabular}{lcccc}
\hline & \multicolumn{2}{c}{$2000-2006$} & \multicolumn{2}{c}{$2006-2012$} \\
& $(1)$ & $(2)$ & $(3)$ & $(4)$ \\
\hline NTM 2001-2006 (\#) & $0.284^{* * *}$ & \multicolumn{3}{c}{$-0.116^{* * *}$} \\
& $(0.053)$ & & $(0.032)$ & \\
NTM 2001-2006 (\%) & & $181.2 * *$ & & 35.5 \\
& & $(75.51)$ & & $(44.75)$ \\
& & & & \\
\hline Observations & 637 & 637 & 618 & 618 \\
R-squared & 0.854 & 0.78 & 0.29 & 0.197 \\
\hline
\end{tabular}

ii. Subprime mortgages

\begin{tabular}{lcccc}
\hline & \multicolumn{2}{c}{$2000-2006$} & \multicolumn{2}{c}{$2006-2012$} \\
& $(1)$ & $(2)$ & $(3)$ & $(4)$ \\
\hline \multirow{2}{*}{ NTM 2001-2006 (\#) } & $0.215^{* * *}$ & \multicolumn{3}{c}{$-0.0679 * * *$} \\
& $(0.021)$ & $(0.015)$ & \\
NTM 2001-2006 (\%) & & 37.61 & & -2.76 \\
& & $(33.26)$ & & $(19.69)$ \\
& & & & 618 \\
Observations & 637 & 637 & 618 & 0.196 \\
R-squared & 0.875 & 0.778 & 0.268 & 0.06
\end{tabular}

NOTE: $* * * \mathrm{p}<0.01, * * \mathrm{p}<0.05, * \mathrm{p}<0.1$. Robust standard errors are in parentheses. Each coefficient represents the result of a separate regression estimated using the same specification as in tables 5 . The dependent variable for each regression is the change in the number of Hispanic homeowners in a county between 2000 and 2006 or 2006 and 2012. 
$\underline{\text { Panel C. Black homeownership }}$

i. Non-traditional mortgages

\begin{tabular}{lcccc}
\hline & \multicolumn{2}{c}{$2000-2006$} & \multicolumn{2}{c}{$2006-2012$} \\
& $(1)$ & $(2)$ & $(3)$ & $(4)$ \\
\hline NTM 2001-2006 (\#) & $0.0316^{*}$ & & $0.0448^{*}$ & \\
& $(0.0190)$ & & $(0.0266)$ & \\
NTM 2001-2006 (\%) & & $153.9^{* * *}$ & & 29.57 \\
& & $(53.28)$ & & $(49.07)$ \\
& & & & \\
\hline Observations & 590 & 590 & 573 & 573 \\
R-squared & 0.224 & 0.234 & 0.229 & 0.208 \\
\hline
\end{tabular}

ii. Subprime mortgages

\begin{tabular}{lcccc}
\hline & \multicolumn{2}{c}{$2000-2006$} & \multicolumn{2}{c}{$2006-2012$} \\
& $(1)$ & $(2)$ & $(3)$ & $(4)$ \\
\hline \multirow{2}{*}{ NTM 2001-2006 (\#) } & $0.0294^{* *}$ & \multicolumn{3}{c}{0.00326} \\
& $(0.0129)$ & & $(0.00753)$ \\
NTM 2001-2006 (\%) & & $59.35^{* * *}$ & & -20.04 \\
& & $(21.13)$ & $(16.86)$ \\
\hline Observations & 590 & 590 & 573 & 573 \\
R-squared & 0.230 & 0.234 & 0.207 & 0.209 \\
\hline
\end{tabular}

NOTE: $* * * \mathrm{p}<0.01, * * \mathrm{p}<0.05,{ }^{*} \mathrm{p}<0.1$. Robust standard errors are in parentheses. Each coefficient represents the result of a separate regression estimated using the same specification as in table 5 . The dependent variable for each regression is the change in the number of Hispanic homeowners in a county between 2000 and 2006 or 2006 and 2012. 
Table 8. Homeownership regression results, stratified by county income level

$\underline{\text { Panel A. Non-traditional mortgages }}$

\begin{tabular}{lcccccccc}
\hline & \multicolumn{9}{c}{$2000-2006$} & \multicolumn{5}{c}{$2006-2012$} \\
& $\begin{array}{r}\text { Low } \\
\text { Inc. }\end{array}$ & $\begin{array}{r}\text { High } \\
\text { Inc. }\end{array}$ & $\begin{array}{r}\text { Low } \\
\text { Inc. }\end{array}$ & $\begin{array}{r}\text { High } \\
\text { Inc. }\end{array}$ & $\begin{array}{r}\text { Low } \\
\text { Inc. }\end{array}$ & $\begin{array}{r}\text { High } \\
\text { Inc. }\end{array}$ & Low Inc. & High Inc. \\
\hline NTM 2001- & $0.783^{* *}$ & $0.705^{* * *}$ & & & 0.0691 & -0.0677 & & \\
$2006(\#)$ & $(0.333)$ & $(0.115)$ & & & $(0.169)$ & $(0.0919)$ & & \\
NTM 2001- & & & -137.3 & $517.1 * *$ & & & $-166.0^{* *}$ & $-232.0^{* *}$ \\
2006 (\%) & & & $(156.2)$ & $(218.4)$ & & & $(80.65)$ & $(92.79)$ \\
& & & & & & & & \\
Observations & 189 & 564 & 189 & 564 & 193 & 578 & 193 & 578 \\
R-squared & 0.502 & 0.703 & 0.479 & 0.568 & 0.506 & 0.569 & 0.516 & 0.570
\end{tabular}

Panel. B. Subprime mortgages

\begin{tabular}{lcccccccc}
\hline & \multicolumn{3}{c}{$2000-2006$} & & & \multicolumn{2}{c}{$2006-2012$} \\
& $\begin{array}{l}\text { Low } \\
\text { Inc. }\end{array}$ & $\begin{array}{c}\text { High } \\
\text { Inc. }\end{array}$ & $\begin{array}{c}\text { Low } \\
\text { Inc. }\end{array}$ & $\begin{array}{c}\text { High } \\
\text { Inc. }\end{array}$ & $\begin{array}{c}\text { Low } \\
\text { Inc. }\end{array}$ & High Inc. & Low Inc. & High Inc. \\
\hline $\begin{array}{l}\text { Subprime } \\
2001-2006\end{array}$ & $0.352^{*}$ & $0.414 * * *$ & & & -0.005 & $-0.118^{* * *}$ & & \\
$(\#)$ & $(0.190)$ & $(0.0777)$ & & & $(0.0931)$ & $(0.0437)$ & & \\
$\begin{array}{l}\text { Subprime 2001- } \\
2006(\%)\end{array}$ & & & -80.31 & 56.69 & & & $-78.34 * * *$ & $-215.6^{* * *}$ \\
& & & $(56.71)$ & $(95.08)$ & & & $(24.95)$ & $(50.95)$ \\
Observations & 189 & 564 & 189 & 564 & 193 & 578 & 193 & 578 \\
R-squared & 0.498 & 0.666 & 0.483 & 0.560 & 0.505 & 0.582 & 0.524 & 0.581
\end{tabular}

NOTE: $* * * p<0.01,{ }^{* *} \mathrm{p}<0.05, * \mathrm{p}<0.1$. Robust standard errors are in parentheses. Each coefficient represents the result of a separate regression estimated using the same specification as in tables 5 . The dependent variable for each regression is the change in the number of homeowners in a county between 2000 and 2006 or 2006 and 2012. "Low income counties" are those with median income below the $1^{\text {st }}$ quartile; "High income counties" represent the remainder. 


\section{Appendix A: Pairwise Correlation Coefficients}

2000-2006

\# NTM 2001-2006

$\%$ NTM 2001-2006

\# Subprime 2001-2006

$\%$ Subprime 2001-2006

\# NTM 2001-2006

$\%$ NTM 2001-2006

\# Subprime 2001-2006

$\%$ Subprime 2001-2006

\# NTM 2001-2006

$\%$ NTM 2001-2006

\# Subprime 2001-2006

\% Subprime 2001-2006

\# NTM 2001-2006

$\%$ NTM 2001-2006

\# Subprime 2001-2006

\% Subprime 2001-2006

\# NTM 2001-2006

\% NTM 2001-2006

\# Subprime 2001-2006

\% Subprime 2001-2006

\# NTM 2001-2006

$\%$ NTM 2001-2006

\# Subprime 2001-2006

\% Subprime 2001-2006

\# NTM 2001-2006

\% NTM 2001-2006

\# Subprime 2001-2006

\% Subprime 2001-2006

\# NTM 2001-2006

$\%$ NTM 2001-2006

\# Subprime 2001-2006

\% Subprime 2001-2006
2006-2012

2000-2012

Change in the Number of Homeowners

$\begin{array}{lcc}0.75 * * * & -0.59 * * * & 0.32 * * * \\ 0.43 * * * & -0.28 * * * & 0.22 * * * \\ 0.71 * * * & -0.63 * * * & 0.26 * * * \\ 0.30 * * * & -0.33 * * * & 0.06 *\end{array}$

Change in the Homeownership Rate
$0.13 * * *$
$-0.21 * * *$
$-0.10 * * *$
$0.10^{* * *}$
$-0.25 * * *$
$-0.18 * * *$
$0.13 * * *$
$-0.20 * * *$
$-0.09 *$
0.01
$-0.21 * * *$
$-0.22 * * *$

Change in the Number of Young Homeowners

$\begin{array}{ccc}0.005 & -0.83 * * * & -0.71 * * * \\ 0.09 * * & -0.45^{* * *} & -0.33^{* * *} \\ -0.04 & -0.83^{* * *} & -0.74 * * * \\ 0.03 & -0.41 * * * & -0.34 * * *\end{array}$

Change in the Number of Hispanic Homeowners

$\begin{array}{lcl}0.88 * * * & -0.24 * * * & 0.74 * * * \\ 0.44 * * * & -0.10 * & 0.38 * * * \\ 0.90 * * * & -0.20 * * * & 0.78 * * * \\ 0.42 * * * & -0.06 & 0.38 * * *\end{array}$

Change in the Number of Black Homeowners
$0.18^{* * *}$
$-0.15^{* * *}$
0.04
$0.23 * * *$
$-0.06$
$0.14 * * *$
$0.18 * * *$
$-0.22 * * *$
$-0.001$
$0.21 * * *$
$-0.15 * * *$
0.05

Change in the Homeownership Rate of Young Homeowners
$0.09^{* *}$
$-0.15^{* * *}$
$-0.09 * *$
$0.11 * * *$
$-0.27 * * *$
$-0.24 * * *$
$0.10 * * *$
$-0.14 * * *$
$-0.08 * *$
$0.06 *$
$-0.18 * * *$
$-0.17 * * *$

Change in the Homeownership Rate of Hispanic Homeowners
0.01
$-0.10 * *$
$-0.06 *$
$-0.004$
$-0.18 * * *$
$-0.13 * * *$
0.01
$-0.10 * *$
$-0.06 *$
$-0.01$
$-0.13 * * *$
$-0.08 * *$

Change in the Homeownership Rate of Black Homeowners

$\begin{array}{llc}0.01 & -0.05 & -0.02 \\ 0.03 & -0.02 & 0.03 \\ 0.02 & -0.05 & -0.02 \\ 0.07 & -0.07 & -0.02\end{array}$

NOTE: $* * * \mathrm{p}<0.01, * * \mathrm{p}<0.05, * \mathrm{p}<0.1$. 


\section{Appendix B: Comparison between models with and without fixed effects and with population weights}

(1)
$0.677 * * *$
$0.656 * * *$
$0.745^{* * *}$
$(0.151)$
$(0.131)$
$(0.170)$

NTM 2001-2006 (\%)

Number of Households

Owner Occupied 2000

(\%)

Mean Household Size

College Educated (\%)

25-34 (\%)

$35-44(\%)$

$45-54(\%)$

$55-64(\%)$

Family with Children (\%)

Foreign Born (\%)

Hispanic (\%)

Black (\%)

Unemployment (\%)

Median Household

Income (000)

Median Rent

Median House Value

(000)

Rent to Value

Value to Income

(0.151)

$-0.0441 * * *$

$-0.0413 * * *$

(0.0156)

$-49.26$

(122.4)

$-17,945 * * *$

$(4,623)$

$293.3 * * *$

(94.67)

787.4*

(458.4)

95.44

(760.3)

$-792.9$

(857.5)

492.7

(699.6)

$1,027 * * *$

(239.6)

98.03

(300.7)

63.72

(133.2)

$-165.0 * *$

(70.42)

208.2

(498.3)

$1.096 * * *$

(0.281)

$-28.00^{*}$

(15.64)

$-256.3^{* * *}$

(49.28)

10,058

$(12,759)$

$14,889 * * *$
(3)
(0.0141)

$-161.7$

(108.2)

$-11,751 * * *$

$(4,281)$

$350.1 * * *$

(61.88)

$970.8 * *$

(438.9)

246.6

(668.3)

$-1,141$

(915.2)

$2,273 * * *$

(511.7)

$927.3 * * *$

(228.6)

$-7.126$

(285.9)

170.5*

(95.18)

$-158.4 * * *$

(41.96)

$-333.3$

(316.9)

$1.262 * * *$

(0.275)

$-35.94 * *$

(14.94)

$-266.0 * * *$

(48.82)

$34,343 * * *$

$(11,303)$

$-0.0600 * * *$

(0.0130)

$-1,380$ *

(776.2)

$-24,853 *$

$(14,175)$

$788.6^{* * *}$

(221.5)

2,071 *

$(1,116)$

$-1,350$

$(2,973)$

542.2

$(4,204)$

$6,812 * * *$

$(1,890)$

$2,992 * *$

$(1,161)$

387.4

(620.6)

89.52

(272.3)

$-640.3 * * *$

(215.4)

$-597.9$

$(1,289)$

$1.686 * * *$

(0.626)

$-80.50 * *$

(36.51)

$-261.1 * *$

(113.0)

$85,548 * * *$

$(32,799)$

15,127

$16,636^{* * *}$
(4)

(5)

(6)

$\begin{array}{ccc}398.9 * * & 242.9 & 1,267 * * \\ (193.3) & (185.0) & (605.6) \\ 0.00183 & 0.00333 & -0.0102 * \\ (0.00986) & (0.0106) & (0.00554)\end{array}$

$-58.63$

(123.1)

$-16,365^{* * *}$

$(4,760)$

$250.1 * *$

(97.84)

510.8

(468.1)

432.3

(856.3)

$-1,494$

(1,034)

245.9

(687.8)

$941.0 * * *$

(239.8)

64.61

(277.9)

64.96

(124.8)

$-231.7 * * *$

(70.73)

$-695.7$

(607.9)

$0.863 * * *$

(0.293)

$-14.38$

(14.93)

$-220.8^{* * *}$

(53.00)

$-3,023$

$(14,117)$
$-166.3$

(104.4)

$-9,318 * *$

$(4,186)$

$341.2 * * *$

(65.96)

1,111 **

(480.1)

247.5

(705.2)

$-1,080$

(946.5)

$2,291 * * *$

(554.6)

$1,089 * * *$

(225.7)

$-89.89$

(281.0)

$175.5^{* *}$

(87.48)

$-203.4 * * *$

(47.08)

$-795.8 * *$

(358.3)

$0.718 * * *$

(0.273)

$-5.356$

(14.73)

$-212.3 * * *$

(44.47)

12,028

$(12,326)$

$8,786^{* * *}$
$-1,376^{*}$

(753.9)

$-21,865$

$(14,718)$

805.1 ***

(239.6)

3,137 *

$(1,630)$

$-844.7$

$(3,289)$

179.5

$(4,241)$

7,256 ***

(2,057)

$3,349 * * *$

$(1,109)$

$-39.56$

(620.8)

132.5

(261.6)

$-839.9 * * *$

(234.2)

$-2,965 * *$

$(1,244)$

$1.421 * *$

(0.704)

$-69.26$

(46.14)

$-309.3 * *$

(130.7)

61,886*

$(37,128)$

11,127 


\begin{tabular}{|c|c|c|c|c|c|c|}
\hline \multirow{3}{*}{ HPI Variance ( 5 years) } & $(3,954)$ & $(3,783)$ & $(9,911)$ & $(3,852)$ & $(3,353)$ & $(9,418)$ \\
\hline & $-2,625$ & 7,296 & $-16,478$ & $-11,909$ & $-2,739$ & 1,432 \\
\hline & $(14,595)$ & $(11,282)$ & $(28,153)$ & $(14,815)$ & $(10,373)$ & $(30,029)$ \\
\hline Projected 1 Year HPI & 255.8 & -108.3 & 1,442 & 237.8 & -156.3 & 702.7 \\
\hline Change & $(245.3)$ & $(239.2)$ & $(1,167)$ & $(243.5)$ & $(242.2)$ & $(1,153)$ \\
\hline \multirow[t]{2}{*}{ MSA (ref.=Not MSA) } & -905.1 & 12.55 & 2,438 & $-1,748$ & -774.4 & $-2,510$ \\
\hline & (956.9) & $(1,013)$ & $(3,486)$ & $(1,081)$ & $(1,057)$ & $(4,387)$ \\
\hline \multirow{2}{*}{$\begin{array}{l}\text { Suburban County } \\
\text { (ref.=Central County) }\end{array}$} & -575.4 & 621.4 & 6.026 & -239.0 & 986.4 & 570.0 \\
\hline & (782.4) & $(928.5)$ & $(1,962)$ & (855.4) & (940.3) & $(2,421)$ \\
\hline \multirow[t]{2}{*}{ Constant } & $-44,037 *$ & $-86,238^{* * *}$ & $-130,437 * *$ & $-4,869$ & $-65,334 * * *$ & $-131,380^{*}$ \\
\hline & $(24,382)$ & $(23,030)$ & $(64,718)$ & $(26,458)$ & $(24,478)$ & $(70,114)$ \\
\hline State FE & YES & NO & NO & YES & $\mathrm{NO}$ & $\mathrm{NO}$ \\
\hline Population Weighted & NO & NO & YES & NO & NO & YES \\
\hline Observations & 746 & 746 & 746 & 746 & 746 & 746 \\
\hline R-squared & 0.501 & 0.420 & 0.497 & 0.412 & 0.314 & 0.399 \\
\hline \multirow{2}{*}{$\begin{array}{l}\text { Likelihood-ratio test } \\
\text { (Assumption: No fixed } \\
\text { effect nested in fixed } \\
\text { effect model) }\end{array}$} & \multicolumn{3}{|c|}{ LR $\operatorname{chi} 2(49)=117.84$} & \multicolumn{3}{|c|}{ LR $\operatorname{chi} 2(49)=115.71$} \\
\hline & \multicolumn{3}{|c|}{ Prob $>\operatorname{chi} 2=0.000$} & \multicolumn{3}{|c|}{ Prob $>$ chi $2=0.000$} \\
\hline
\end{tabular}

NOTE: $* * * p<0.01, * * p<0.05, * p<0.1$. Robust standard errors are in parentheses. The dependent variable for each regression is the change in the number of homeowners in a county between 2000 and 2012. 


\section{Appendix C: Combined NTM and Subprime Models}

Panel A: Change in Number of Homeowners as Dependent Variable

\begin{tabular}{lccc}
\hline & $2000-2006$ & $2006-2012$ & $2000-2012$ \\
& $(1)$ & $(2)$ & $(3)$ \\
\hline NTM 2001-2006 (\#) & $0.592^{* *}$ & 0.228 & $0.820^{* *}$ \\
& $(0.235)$ & $(0.256)$ & $(0.391)$ \\
Subprime 2001-2006 (\#) & 0.094 & -0.227 & -0.095 \\
& $(0.147)$ & $(0.148)$ & $(0.260)$ \\
\hline Observations & 729 & 729 & 729 \\
R-squared & 0.725 & 0.65 & 0.507 \\
\hline & & & \\
\hline & $2000-2006$ & $2006-2012$ & $2000-2012$ \\
& $(1)$ & $(2)$ & $(3)$ \\
\hline NTM 2001-2006 (\%) & $759.5 * * *$ & 176.2 & $824.4 * * *$ \\
& $(243.2)$ & $(127.9)$ & $(268.6)$ \\
Subprime 2001-2006 (\%) & -18.25 & $-179.6 * * *$ & $-216.8 * *$ \\
& $(89.7)$ & $(56.8)$ & $(101.7)$ \\
\hline Observations & 729 & 729 & 729 \\
R-squared & 0.617 & 0.64 & 0.418 \\
\hline
\end{tabular}

NOTE: $* * * \mathrm{p}<0.01, * * \mathrm{p}<0.05, * \mathrm{p}<0.1$. Robust standard errors are in parentheses. The dependent variable is the change in the number of homeowners in a county between 2000 and 2006 or 2006 and 2012. The regressions are estimated using the same specification as in tables 5 but with the measure of NTM and Subprime included in the same model. 
Panel B: Change in Homeownership Rate as Dependent Variable

\begin{tabular}{lccc}
\hline & $2000-2006$ & $2006-2012$ & $2000-2012$ \\
& $(1)$ & $(2)$ & $(3)$ \\
\hline \multirow{2}{*}{ NTM 2001-2006 (\#) } & -0.0510 & 0.0474 & -0.0118 \\
& $(0.105)$ & $(0.144)$ & $(0.123)$ \\
Subprime 2001-2006 (\#) & 0.0355 & -0.0585 & -0.0255 \\
& $(0.0446)$ & $(0.0540)$ & $(0.0344)$ \\
\hline Observations & 729 & 729 & 729 \\
R-squared & 0.410 & 0.275 & 0.388 \\
\hline & & & \\
& & & \\
\hline & $2000-2006$ & $2006-2012$ & $2000-2012$ \\
& $(1)$ & $(2)$ & $(3)$ \\
\hline \multirow{2}{*}{ NTM 2001-2006 (\%) } & $-2.16 \mathrm{e}-05$ & $-5.53 \mathrm{e}-05$ & $-5.58 \mathrm{e}-05$ \\
& $(3.54 \mathrm{e}-05)$ & $(4.11 \mathrm{e}-05)$ & $(4.21 \mathrm{e}-05)$ \\
Subprime 2001-2006 (\%) & $9.15 \mathrm{e}-06$ & $5.20 \mathrm{e}-05$ & $3.65 \mathrm{e}-05$ \\
& $(2.22 \mathrm{e}-05)$ & $(4.04 \mathrm{e}-05)$ & $(4.11 \mathrm{e}-05)$ \\
\hline Observations & 729 & 729 & 729 \\
R-squared & 0.273 & 0.413 & 0.389 \\
\hline
\end{tabular}

NOTE: $* * * p<0.01, * * p<0.05, * p<0.1$. Robust standard errors are in parentheses. The dependent variable is the change in the homeownership rate in a county between 2000 and 2006 or 2006 and 2012. The regressions are estimated using the same specification as in tables 5 but with the measure of NTM and Subprime included in the same model. 